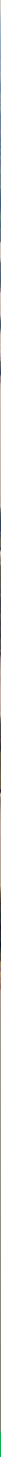

\title{
Impact analysis for the purpose of the introduction of DROPLET version 1.3.2
}



Impact analysis for the purpose of the introduction of DROPLET version 1.3.2 
This WOt-technical report was produced in accordance with the Quality Management System of the Statutory Research Tasks Unit for Nature \& the Environment, part of Wageningen University \& Research.

The mission of the Statutory Research Tasks Unit for Nature and the Environment (WOT Natuur \& Milieu) is to carry out statutory research tasks on issues relating to nature and the environment. These tasks are implemented in order to support the Dutch Minister of Agriculture, Nature and Food Quality, who is responsible for these issues. We provide data about agri-environment, biodiversity and soil information to compile reports as part of national and international obligations, and we work on products of the PBL Netherlands Environmental Assessment Agency, such as the Assessment of the Human Environment reports.

\section{Disclaimer WOt-publicaties}

The 'WOt-technical reports' series presents the findings of research projects implemented for the Statutory Research Tasks Unit for Nature \& the Environment by various centres of expertise.

WOt-technical report 160 presents the findings of a research project commissioned and funded by the Dutch Ministry of Agriculture, Nature and Food Quality (LNV). 


\section{Impact analysis for the purpose of the introduction of DROPLET version 1.3.2}

A. de Jong ${ }^{1}$, A. Poot ${ }^{1}$ \& P.I Adriaanse ${ }^{2}$

1) Dutch Board for the Authorisation of Plant Protection Products and Biocides (Ctgb)

2) Waqeningen Environmental Research

Project WOT-04-008-024 


\title{
Abstract
}

Jong, A. de, A. Poot \& P.I. Adriaanse (2019). Impact analysis for the purpose of the introduction of DROPLET version 1.3.2. Wageningen, the Statutory Research Tasks Unit for Nature \& the Environment (WOT Natuur \& Milieu). WOttechnical report 160. 54 p.; 2 Fig; 4 Tabs; 4 Refs; 2 Annex.

The user-friendly software tool DROPLET (acronym for DRinkwater uit OPpervlaktewater- Landbouwkundig gebruik Evaluatie Tool) assists the Dutch Board for the Authorisation of Plant Protection Products and Biocides (Ctgb) in evaluating whether pesticides may exceed the $0.1 \mu \mathrm{g} / \mathrm{L}$ standard in one of the Dutch surface water abstraction points for drinking water production. Based upon Good Agricultural Practice DROPLET uses the peak concentration in the FOCUS D3 ditch (with spray drift deposition according to Dutch numbers) as starting point for the final, expected concentrations at the abstraction points situated in the larger waterbodies downstream. Results of this impact analysis showed, that for the plant protection products which have been authorized in the period 2014 2018, for which the current version of DROPLET (1.2) was used in the risk assessment, the use of the new DROPLET version (1.3.2.) has no effect on the conclusion for the drinking water criterion. The predicted concentration in surface water at drinking water abstraction points was below the threshold of $0.1 \mu \mathrm{g} / \mathrm{L}$ for all products for all abstraction points for both the old and the new model suite. Therefore, we recommend implementing the new DROPLET version in the national authorization procedure.

Keywords: surface water abstraction for drinking water production, pesticides, registration, DROPLET model suite

\section{Referaat}

Jong, A. de, A. Poot \& P.I. Adriaanse (2019). Impactanalyse ten behoeve van de introductie van DROPLET 1.3.2. Wettelijke Onderzoekstaken Natuur \& Milieu, WOt-technical report 160. 54 blz.; 2 fig.; 4 tab.; 4 ref; 2 Bijlagen.

Het gebruikersvriendelijke instrument DROPLET (acroniem voor DRinkwater uit OPpervlaktewater-Landbouwkundig gebruik Evaluatie Tool) ondersteunt het Nederlandse College voor de toelating van gewasbeschermingsmiddelen en biociden (Ctgb) bij het evalueren of gewasbeschermingsmiddelen de drinkwater norm van $0.1 \mu \mathrm{g} / \mathrm{L}$ overschrijden in één van de negen innamepunten van oppervlaktewater voor drinkwaterbereiding. Uitgaande van Goed Landbouwkundig Gebruik gebruikt DROPLET de piekconcentratie in de FOCUS D3 sloot (met spuitdriftdepositie volgens Nederlandse cijfers) als startpunt voor de berekening van de uiteindelijke concentratie bij de drinkwater innamepunten die benedenstrooms in grotere wateren zijn gesitueerd. Resultaten van de impactanalyse laten zien dat voor de gewasbeschermingsmiddelen die zijn toegelaten in de periode 2014 - 2018 en waarvoor de huidige versie van DROPLET (1.2) is gebruikt in de risicobeoordeling, het gebruik van de nieuwe DROPLET-versie (1.3.2) geen effect heeft op de conclusie ten aanzien van het drinkwatercriterium. De voorspelde concentratie in oppervlaktewater bij drinkwaterinnamepunten lag onder de norm van $0,1 \mu \mathrm{g} / \mathrm{L}$, voor alle innamepunten voor zowel de oude als de nieuwe modellentrein. Daarom bevelen we aan om de nieuwe DROPLET versie in de nationale beoordelingsprocedure te implementeren.

Trefwoorden: extractie van oppervlaktewater voor productie van drinkwater, gewasbeschermingsmiddel, registratie, DROPLET modellentrein

Photo cover: Shutterstock

(C) $2019 \quad$ Wageningen Environmental Research

P.O. Box 47, 6700 AA Wageningen

Phone: (0317) 4819 13; e-mail: paulien.adriaanse@wur.nl

\author{
College voor de toelating van gewasbeschermingsmiddelen en biociden \\ P.O. box 8030, NL6710 AA Ede, The Netherlands \\ Phone: (0317) 4718 99; e-mail: anton.poot@ctgb.nl
}

The Statutory Research Tasks Unit for Nature and the Environment (WOT Natuur \& Milieu; an unit under the auspices of the Stichting Wageningen Research), PO Box 47, NL 6700 AA Wageningen, T +31 3174854 71, info.wnm@wur.nl, www.wur.nl/wotnatuurenmilieu. WOT Natuur \& Milieu is part of Wageningen University \& Research.

This report can be downloaded free of charge from https://doi.org/10.18174/508021 or from www.wur.nl/wotnatuurenmilieu. WOT Natuur \& Milieu provides no printed copies of reports.

- Acquisition, duplication and transmission of this publication is permitted with clear acknowledgement of the source.

- Acquisition, duplication and transmission is not permitted for commercial purposes and/or monetary gain.

- Acquisition, duplication and transmission is not permitted of any parts of this publication for which the copyrights clearly rest with other parties and/or are reserved.

WOT Natuur \& Milieu assumes no liability for any losses resulting from the use of the research results or recommendations in this report. 


\section{Preface}

The present study has been commissioned by the WOt programme WOT-04-008-024 to the Ctgb, the Dutch Board for the Authorization of Plant Protection Products and Biocides. The set-up as well as its results and conclusions have been reviewed by dr. Erik van den Berg and ir. Paulien Adriaanse of the Environmental Risk Assessment team of Wageningen Environmental Research (ERA-WENR).

This study considers the impact of updating the DROPLET 1.2 model suite to the DROPLET 1.3.2 model suite on the current risk assessment with respect to the drinking water from surface water criterion. It does so by considering 24 substance-crop combinations, taken from a selection of plant protection products for which registration was requested in the period 2014-2018. So, instead of the hypothetical substances applied at $1 \mathrm{~kg} / \mathrm{ha}$ considered in the Adriaanse \& Beltman report (2017) the present study considers 'real' substances and application patterns, as submitted for authorization at Ctgb. 



\section{Contents}

Preface

Summary

Samenvatting

Fout! Bladwijzer niet gedefinieerd.

Introduction

2 Method

3 Results \& discussion

4 Conclusions and recommendations

25

References

List of used abbreviations

29

Justification 31

Annex $1 \quad$ Substance input parameters and model input parameters

Annex 2 Graphical representation of concentration in water layer
13

15

19

27

33

9

11

41 



\section{Summary}

The user-friendly software tool DROPLET (acronym for DRinkwater uit OPpervlaktewater-

Landbouwkundig gebruik Evaluatie Tool) assists the Dutch Board for the Authorisation of Plant Protection Products and Biocides (Ctgb) in evaluating whether pesticides may exceed the $0.1 \mu \mathrm{g} / \mathrm{L}$ standard in one of the Dutch surface water abstraction points for drinking water production. Based upon Good Agricultural Practice DROPLET uses the peak concentration in the FOCUS D3 ditch (with spray drift deposition according to Dutch numbers) as starting point for the final, expected concentrations at the abstraction points situated in the larger waterbodies downstream.

The Dutch Ministry of Agriculture, Nature and Food Quality has commissioned a new version of DROPLET that makes use of the most recently released versions of the FOCUS models, i.e. the FOCUSMACRO 5.5.3 model calculating pesticide losses via drainage plus the FOCUS-TOXSWA 4.4.3 model calculating next the resulting concentration in the FOCUS D3 ditch. The update resulted in increased concentrations at the abstraction points, up to a factor of 2.5, as reported in Wot-technical report 100 (Adriaanse \& Beltman, 2017). It was shown that this was caused by an increase in the drainage flux calculated by FOCUS MACRO 5.5.3. So, the new release of DROPLET may have impact on decisions made in the registration procedure of the Netherlands when used in combination with FOCUS-MACRO 5.5.3. Therefore the ministry requested an impact analysis, enabling them to make an informed decision on implementation of DROPLET version 1.3.2 in the authorization procedure in the Netherlands.

To determine the potential impact of the new DROPLET version, we compared results of the old model suite (FOCUS-SWASH 3.1, FOCUS-MACRO 4.4.2, FOCUS-TOXSWA 3.3.1 and DROPLET 1.2) to those of the recently released model suite (FOCUS-SWASH 5.3, including the substance database SPIN 3.3, FOCUS-MACRO 5.5.3, FOCUS-TOXSWA 4.4.3 and DROPLET 1.3.2) for a selection of all the plant protection products authorized in the past five years $(2014-2018)$, for which DROPLET was used in the risk assessment.

Results of the impact analysis showed, that for the plant protection products which have been authorized in the period 2014 - 2018, for which the current version of DROPLET (1.2) was used in the risk assessment, the use of the new DROPLET version (1.3.2.) has no effect on the conclusion for the drinking water criterion. The predicted concentration in surface water at drinking water abstraction points was below the threshold of $0.1 \mu \mathrm{g} / \mathrm{L}$ for all products, for all abstraction points for both the old and the new model suite.

The results of the impact study lead to other insights than the results of the Wot-technical report 100, where the new DROPLET 1.3.2 model suite often resulted in clearly higher concentrations at the drinking water abstraction points than the old DROPLET 1.2 suite ánd where the concentrations at the drinking water abstraction points of some hypothetical substances ( $D, G$ and $H$ ) were above the threshold of $0.1 \mu \mathrm{g} / \mathrm{L}$. The reasons for these differences are:

i. the present impact study uses actual application rates, ranging between 0.01 to $0.1 \mathrm{~kg} / \mathrm{ha}$, while in the former WOt-technical report 100 the application rate was $1 \mathrm{~kg} / \mathrm{ha}$ for all substances, i.e. a factor 10 to 100 larger (thus leading to concentrations of a factor 10 to 100 lower in the impact analysis);

ii. the 15 substances of the impact analysis are less sensitive to leaching via drains to surface water than substances $D, G$ and even $H$ and thus lead to lower concentrations in surface water. (N.B. Note that D and G are very sensitive to leaching to drains because of their low sorption coefficient $\mathrm{K}_{\mathrm{oc}}$ of $10 \mathrm{~L} / \mathrm{kg}$ and $\mathrm{H}$ as well due to its combination of relatively low $\mathrm{K}_{\mathrm{oc}}$ of $100 \mathrm{~L} / \mathrm{kg}$ coupled to a long half-life in soil of $300 \mathrm{~d}$ )

iii. due to their lower sensitivity for leaching to drains the peak concentration in the D3 ditch of the impact study is nearly always caused by spray drift deposition onto the D3 ditch. (N.B. the 
D3 ditch is the starting point for calculation of concentration at the drinking water abstraction point.) In the impact analysis a drift deposition percentage of 0.5 was used, while in the WOttechnical report 100 a percentage of 1 was used, i.e. twice as large. So, for substances where spray drift deposition caused the peak concentration in the D3 ditch in both studies, the impact analysis led to lower concentrations than the WOt-technical report 100 study.

So, the overall conclusion is that the study of the WOt-technical report 100 led to too conservative concentrations in the drinking water abstraction points as demonstrated by the results of the more realistic calculations of the present impact analysis.

Based on the impact analysis, it can be concluded that implementation of the new DROPLET model version, to be used in collaboration with the newest release of the FOCUS models, is not expected to have a significant impact on the risk assessment of plant protection product regarding the drinking water criterion. Therefore, for pragmatic reasons, we recommend implementing the new DROPLET version in the national authorization procedure. 


\section{Samenvatting}

Het gebruikersvriendelijke instrument DROPLET (acroniem voor DRinkwater uit OPpervlaktewaterLandbouwkundig gebruik Evaluatie Tool) ondersteunt het Nederlandse College voor de toelating van gewasbeschermingsmiddelen en biociden (Ctgb) bij het evalueren of gewasbeschermingsmiddelen de drinkwater norm van $0.1 \mu \mathrm{g} / \mathrm{L}$ overschrijden in één van de negen innamepunten van oppervlaktewater voor drinkwaterbereiding.

Het ministerie van Landbouw, Natuur en Voedselkwaliteit (LNV) heeft opdracht gegeven om een nieuwe versie van DROPLET te maken, die gebruik maakt van de meest recent uitgebrachte versies van de FOCUS modellen, i.e. het FOCUS-MACRO 5.5.3 model dat de afvoer van bestrijdingsmiddel via drainage berekent plus het FOCUS-TOXSWA 4.4.3 model dat vervolgens de concentratie in de FOCUS D3 sloot berekent. Het bleek dat de update tot een factor 2,5 hogere concentraties bij de drinkwaterinnamepunten kon leiden, zoals beschreven in WOt-technical report 100 (Adriaanse \& Beltman, 2017). In dit rapport werd aangetoond dat deze toename werd veroorzaakt door een toename in de drainageflux berekend door FOCUS-MACRO 5.5.3. Dus de nieuwe versie van DROPLET zou een impact kunnen hebben op de beslissingen die genomen worden in de beoordelingsprocedure door het Ctgb, wanneer deze nieuwe versie gebruikt wordt in combinatie met FOCUS-MACRO 5.5.3. Daarom heeft het ministerie opdracht gegeven voor een impactanalyse, zodat zij een geïnformeerde beslissing kunnen nemen ten aanzien van de implementatie van DROPLET versie 1.3.2 in de beoordelingsprocedure in Nederland.

Om de potentiele impact van de nieuwe DROPLET-versie te bepalen, zijn resultaten vergeleken die zijn berekend met de vorige modellentrein (FOCUS-SWASH 3.1, FOCUS-MACRO 4.4.2, FOCUS-TOXSWA 3.3.1 en DROPLET 1.2) met die van de meer recent uitgebrachte modellentrein (FOCUS-SWASH 5.3, inclusief de stoffendatabase SPIN 3.3, FOCUS-MACRO 5.5.3, FOCUS-TOXSWA 4.4.3 en DROPLET 1.3.2) voor een selectie van alle gewasbeschermingsmiddelen toegelaten in de laatste vijf jaar (2014 2018), waarvoor DROPLET is gebruikt in de risicobeoordeling.

Resultaten van de impactanalyse laten zien dat voor de gewasbeschermingsmiddelen die zijn toegelaten in de periode 2014 - 2018 en waarvoor DROPLET is gebruikt in de risicobeoordeling, het gebruik van de nieuwe DROPLET-versie (1.3.2) geen effect heeft op de conclusie ten aanzien van het drinkwatercriterium. De voorspelde concentratie in oppervlaktewater bij drinkwaterinnamepunten lag onder de norm van $0,1 \mu \mathrm{g} / \mathrm{L}$ voor alle innamepunten, voor zowel de oude als de nieuwe modellentrein. Daarom bevelen wij aan om de nieuwe DROPLET-versie te implementeren in de nationale toelatingsprocedure.

De resultaten van de impactstudie leiden tot andere inzichten dan de resultaten van het WOt-technical report 100, waarin de nieuwe DROPLET 1.3.2 modellentrein vaak tot duidelijk hogere concentraties bij de drinkwaterinnamepunten leidde dan de oude DROPLET 1.2 modellentrein, én waarin bovendien de concentraties bij de drinkwater innamepunten voor een paar hypothetische stoffen ( $D$ en $G$ ) boven de drinkwater norm van $0.1 \mu \mathrm{g} / \mathrm{L}$ lagen. Redenen voor deze verschillen zijn:

i. de onderhavige impact studie is gedaan met werkelijke doseringen van 0.01 tot $0.1 \mathrm{~kg} / \mathrm{ha}$, terwijl in het WOt-technical report 100 de dosering $1 \mathrm{~kg} / \mathrm{ha}$ was, i.e. een factor 10 tot 100 hoger (resulterend in concentraties van een factor 10 tot 100 lager in de impact studie);

ii. de 15 middelen van de impact studie zijn minder gevoelig voor uitspoeling via drains naar het oppervlaktewater dan de stoffen D, G en $\mathrm{H}$ en dus leiden de 15 middelen van de impact studie tot lagere concentraties in het oppervlaktewater. (N.B. De stoffen D en G zijn zeer uitspoelingsgevoelig vanwege hun lage sorptiecoëfficiënt $K_{o c}$ van $10 \mathrm{~L} / \mathrm{kg}$ en dit geldt ook voor $\mathrm{H}$ met zijn relatief lage $\mathrm{K}_{\mathrm{oc}}$ van $100 \mathrm{~L} / \mathrm{kg}$ in combinatie met lange halfwaardetijd in de bodem van $300 \mathrm{~d}$ ); 
iii. door de lage gevoeligheid voor uitspoeling via drains naar het oppervlaktewater is de piekconcentratie in de D3 sloot bijna altijd het gevolg van spuitdriftdepositie op de D3 sloot. (N.B. De D3 sloot is het startpunt voor de berekening van de concentratie bij het drinkwaterinnamepunt.) Bij de impactstudie is een spuitdriftdepositie percentage van 0,5 gebruikt, terwijl in het WOt-technical report 100 een percentage van 1 was gebruikt, i.e. twee keer zo hoog. De impactstudie leidde dus tot lagere concentraties dan de studie uit het WOttechnical report 100 voor middelen waarbij spuitdriftdepositie de piek in de D3 sloot veroorzaakte.

De algehele conclusie is dus dat het WOt-technical report 100 tot te conservatieve concentraties in de drinkwaterinnamepunten leidde, zoals aangetoond in de onderhavige impactstudie met meer realistische berekeningen.

Gebaseerd op de impactanalyse, kan worden geconcludeerd dat de implementatie van de nieuwe DROPLET-versie, die gebruikt kan worden met de nieuwste versies van de FOCUS modellen, naar verwachting geen significante impact zal hebben op de risicobeoordeling van gewasbeschermingsmiddelen ten aanzien van het drinkwatercriterium. Uit pragmatisch oogpunt, bevelen we aan om de nieuwe DROPLET-versie te implementeren in de nationale beoordelingsprocedure. 


\section{Introduction}

Ctgb uses the pre-registration software tool DROPLET to predict the concentrations of active substances in surface water at the nine surface water abstraction points for drinking water production. This tool is used in the registration procedure for products based on active substances which are not yet authorised for use in the Netherlands, or with their first authorization less than 3 years ago. DROPLET uses the peak concentration estimated by the European FOCUS Surface Water models in the FOCUS D3 ditch (with spray drift deposition according to Dutch numbers) as starting point for the final, expected concentrations at the abstraction points situated in the larger waterbodies downstream. On request of the Ctgb a new version of DROPLET 1.3.2 was developed, that communicates with the newer released versions of the FOCUS models, i.e. FOCUS-SWASH 5.3 (including the substance database SPIN), FOCUS-MACRO 5.5.3 ${ }^{1}$ and FOCUS-TOXSWA 4.4.3 ${ }^{1}$. Figure 1 gives an overview of the sequence in which these tools and models are used to perform so-called Step 3 FOCUS Surface Water Scenarios simulations (Figure 1).

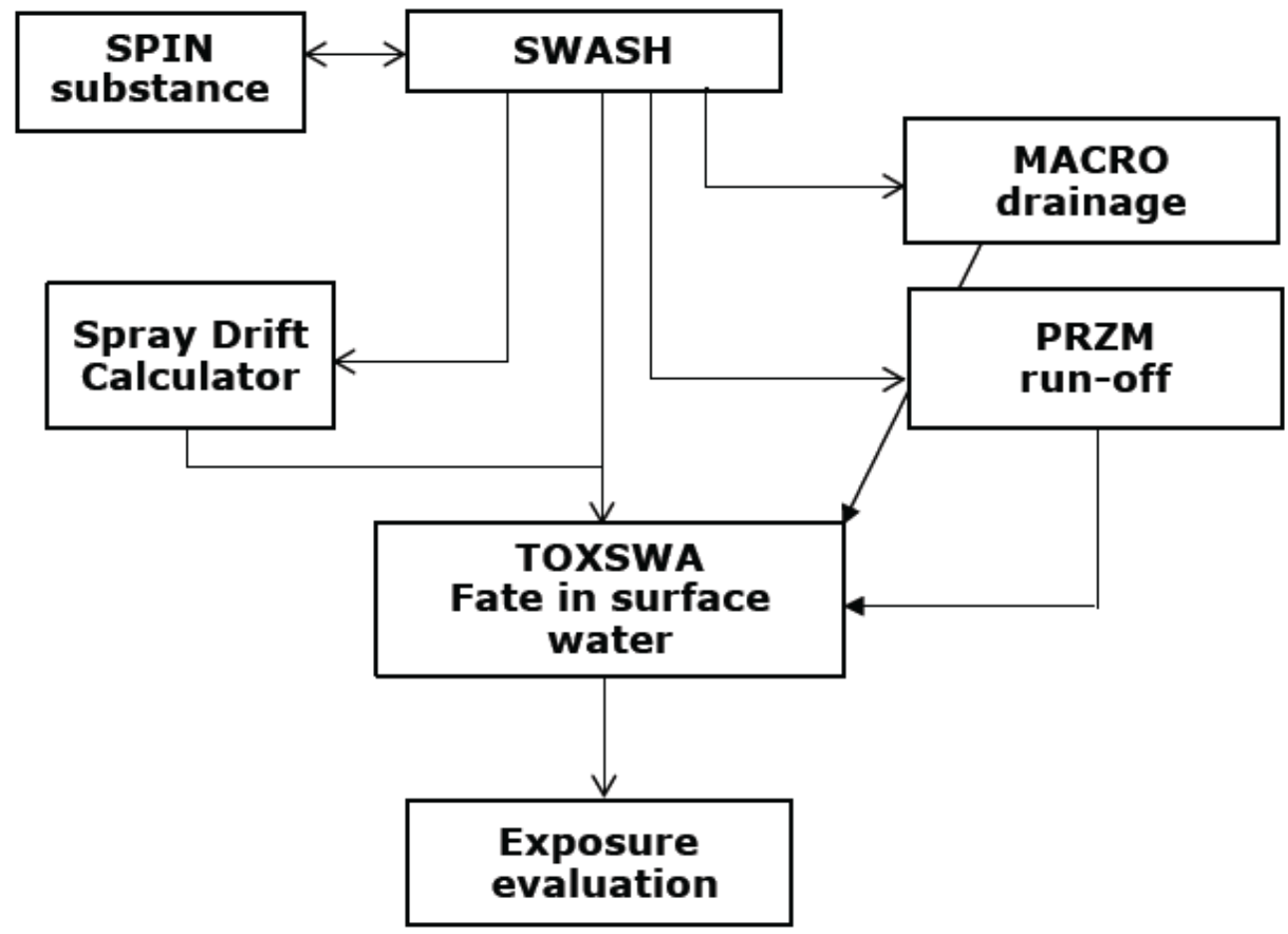

Figure 1 Sequence of tools and models used to calculate pesticide exposure in the proposed Step 3 EU FOCUS Surface Water Scenarios.

Some preliminary calculations performed with the updated version 1.3.2 of DROPLET (coupled to the newer released FOCUS models of SWASH, MACRO and TOXSWA) showed relatively large differences in the Predicted Environmental Concentration in surface water at the drinking water abstraction points (PEC_Tier1), compared to the PEC_Tier1 values calculated by DROPLET 1.2 (coupled to former releases of SWASH, MACRO and TOXSWA). A detailed analysis of the cause of these differences, is reported in Wot-technical report 100 (Adriaanse \& Beltman, 2017). In this report it was demonstrated that the differences in PEC_Tier1 values were nearly entirely due to the increase in pesticide mass in the drainage fluxes of version 5.5.3 of the MACRO model with respect to those of the former version 4.4.2. The increase in calculated drainage flux by MACRO 5.5 .3 is caused by important changes in the

\footnotetext{
${ }^{1}$ At the time of writing of this report the most recent version of FOCUS_MACRO and FOCUS_TOXSWA were version 5.5.4 and 5.5.3 respectively. However, these versions do not deliver significant different results compared to FOCUS_MACRO 5.5.3 and FOCUS_TOXSWA 4.4.3. Therefore, in order to be consistent with the calculations in WOt technical report 100, the same mode versions were used in this report.
} 
numerical solution of the flow and transport equations and some underlying mathematical functions of the MACRO model. When comparing PEC_Tier1 results calculated using both the old and the new model suite, it was shown that concentrations at drinking water intake points could be up to a factor 2.5 higher using the new model versions.

Therefore the Dutch Ministry of Agriculture, Nature and Food Quality decided that an impact analysis of the introduction of DROPLET version 1.3.2 was required, before a decision could be made on the implementation of the new version in the authorization procedure of plant protection products in the Netherlands. This report describes the method and results of an impact analysis, designed to determine the impact of the release of DROPLET 1.3.2 on the national risk assessment of plant protection products. 


\section{Method}

The impact analysis was performed by means of calculations for plant protection products based on active substances new on the Dutch market, authorized in the period 2014-2018. In Table 2, an overview is presented of the products used in the impact analysis. Adriaanse \& Beltman (2017) showed that the impact on the PEC_Tier1 value is largest for compounds that are relatively mobile (Koc around $100 \mathrm{~L} / \mathrm{kg}$ or smaller) and/or persistent in soil (DegT $\mathrm{T}_{50, \text { soil }} 30 \mathrm{~d}$ or greater). Products containing active substances with these properties are highlighted grey in Table 1. All four possible combinations of substance parameters are represented in the selected products (i.e. $\mathrm{K}_{\mathrm{oc}}<100 \mathrm{~L} / \mathrm{kg}$ and DegT 50 ,soil $<$ $30 \mathrm{~d}, \mathrm{~K}_{\mathrm{oc}}>100 \mathrm{~L} / \mathrm{kg}$ and $\mathrm{DegT}_{50, \text { soil }}>30 \mathrm{~d}, \mathrm{~K}_{\mathrm{oc}}<100 \mathrm{~L} / \mathrm{kg}$ and $\mathrm{DegT}_{50, \text { soil }}>30 \mathrm{~d}, \mathrm{~K}_{\mathrm{oc}}>100 \mathrm{~L} / \mathrm{kg}$ and DegT $_{50, \text { soil }}<30 \mathrm{~d}$ ).

For each of the nine surface water abstraction points for drinking water production, the associated acreage in the intake area of 24 different crops is represented in DROPLET. The 6 crops with the highest corresponding acreage for the 9 abstraction points are grass, potatoes, cereals, maize, fruit culture (tall) and sugar beets. In order to limit the total amount of test runs performed for the impact analysis, a selection was made based on the crops with the highest acreage; as a consequence, 4 active substances new on the Dutch market in the period 2014-2018 are discarded from the impact analysis, and for the remaining 15 active substances, not all products and/or applications authorised have been accounted for in model simulations. Please refer to Table 3 for the final list of active substances and corresponding crop scenarios included in the impact analysis.

Calculations were performed with the currently used DROPLET version 1.2 in combination with the former releases of the FOCUS-models (called old suite) and subsequently compared with calculations using the new DROPLET version 1.3.2 with the newer releases of the FOCUS models (called new suite):

\begin{tabular}{|c|c|}
\hline Old suite & New suite \\
\hline FOCUS-SWASH 3.1 & FOCUS-SWASH 5.3 \\
\hline FOCUS-MACRO 4.4 .2 & SPIN $3.3^{*}$ \\
\hline FOCUS-TOXSWA 3.3.1 & FOCUS-MACRO 5.5 .3 \\
\hline DROPLET 1.2 & FOCUS-TOXSWA 4.4 .3 \\
\hline
\end{tabular}

${ }^{*}$ The new suite now includes a SPIN substance database, because all substance input has been taken out of FOCUS-SWASH and entered in a new database called SPIN (acronym for Substance Plug IN, Van Kraalingen et al., 2013)

Calculations were performed based on the critical use pattern of the product in combination with the drift values presented in Evaluation Manual 2.2 (Ctgb, 2018). The use pattern, drift values and substance parameters used in the calculations are reported in Appendix 1 for all products.

Related to the different model versions of the old and new model suite, some model parameter values are different between the two suites. Table 1 presents an overview of these parameters, which especially affect MACRO and TOXSWA. All other model parameters are the same in the calculations for both suites. 
Table 1 Parameter values that differ between the old and new model suite.

\begin{tabular}{lll}
$\begin{array}{l}\text { TOXSWA and DROPLET } \\
\text { Molar activation energy for } \\
\text { the effect of temperature on } \\
\text { transformation rate in water }\end{array}$ & $54 \mathrm{~kJ} / \mathrm{mol}$ & $65.4 \mathrm{~kJ} / \mathrm{mol}$ \\
and in sediment & & \\
\hline $\begin{array}{l}\text { MACRO } \\
\text { soil hydraulic functions }\end{array}$ & Brooks-Corey & Van Genuchten \\
\hline $\begin{array}{l}\text { MACRO } \\
\text { Effect of temperature on } \\
\text { transformation in soil }\end{array}$ & 0.079 & 0.0948 \\
\hline $\begin{array}{l}\text { MACRO and PRZM } \\
\text { Exponent for the effect of } \\
\text { moisture content on }\end{array}$ & 0.7 (PRZM) & \\
transformation rate in soil & & 0.49 (calibrated in \\
\end{tabular}




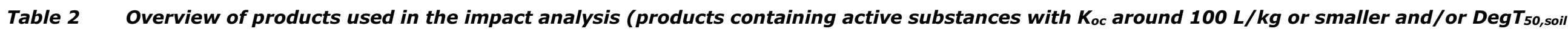
of $30 \mathrm{~d}$ or greater are highlighted grey).

\begin{tabular}{|c|c|c|c|c|c|c|}
\hline Active substance & $\begin{array}{c}\text { Year } \\
\text { authorised }\end{array}$ & Product & Use(s) & $\begin{array}{l}\text { Focus D3 } \\
\text { crop }\end{array}$ & $\begin{array}{l}\text { DegTs0,soil } \\
\text { [d] }\end{array}$ & $\begin{array}{c}\mathrm{K}_{\mathrm{oc}} \\
{[\mathrm{L} / \mathrm{kg}]}\end{array}$ \\
\hline valifenalate & 2018 & Valis M & Potatoes, Vines & $\begin{array}{l}\text { Potatoes, } \\
\text { Pome/stone } \\
\text { fruit late }\end{array}$ & 0.15 & 859 \\
\hline Mandestrobin* & 2018 & SISAM & Oilseed rape & $\begin{array}{l}\text { Spring oilseed } \\
\text { rape }\end{array}$ & 231.2 & 448 \\
\hline cyantraniliprole & 2018 & Benevia & $\begin{array}{l}\text { Bulb vegetables, onions, shallots, garlic, } \\
\text { leek, Cauliflower, broccoli, head cabbage, } \\
\text { Brussels sprout, strawberries, Carrot, other } \\
\text { root and tuber vegetables, Potatoes }\end{array}$ & $\begin{array}{c}\text { Vegetables - } \\
\text { bulb, } \\
\text { Vegetables - } \\
\text { leafy, } \\
\text { Vegetables - } \\
\text { root, Potatoes }\end{array}$ & 32.4 & 193 \\
\hline flupyradifurone & 2018 & Sivanto Prime & $\begin{array}{l}\text { Apple, Pear, Grapevine, Lettuce, Hop, Bulb } \\
\text { flowers, Ornamentals, Tree nursery }\end{array}$ & $\begin{array}{c}\text { Pome/stone } \\
\text { fruits early + } \\
\text { late, } \\
\text { Vegetables - } \\
\text { leafy, Spring } \\
\text { cereals, } \\
\text { Vegetables - } \\
\text { bulb }\end{array}$ & 94.8 & 98.4 \\
\hline Benzovindiflupyr & 2017 & Elatus Era, Elatus Plus & Cereals & $\begin{array}{l}\text { Winter cereals, } \\
\text { spring cereals }\end{array}$ & 184 & 3696 \\
\hline Pyriofenone & 2017 & PROPERTY 180SC & Cereals & $\begin{array}{l}\text { Winter cereals, } \\
\text { spring cereals }\end{array}$ & 117 & 705 \\
\hline Sedaxane & 2017 & Vibrance & Maize & & 100 & 534 \\
\hline Isoxaben & 2017 & AZ 500 & $\begin{array}{l}\text { Pome fruit (Apple, Pear), Winter cereals, } \\
\text { Rhubarb, Onion, shallot, garlic, Witloof } \\
\text { (large-rooted chicory, witloof chicory } \\
\text { (roots), Asparagus, Leek, Ornamentals, }\end{array}$ & $\begin{array}{l}\text { Pome/stone } \\
\text { fruit early } \\
\text { Cereals, winter } \\
\text { Field beans }\end{array}$ & 94.3 & 354 \\
\hline
\end{tabular}




\begin{tabular}{|c|c|c|c|c|c|c|}
\hline & & & $\begin{array}{l}\text { Grass seed crops (Bluegrass, Fescue), } \\
\text { fodder grassland, clover (fodder crops), } \\
\text { managed amenity turf }\end{array}$ & $\begin{array}{l}\text { Vegetables - } \\
\text { bulb, } \\
\text { Vegetables - } \\
\quad \text { leafy, } \\
\text { Grass, alfalfa }\end{array}$ & & \\
\hline Halauxifen-methyl & 2016 & ARYLEX TECHNICAL & Cereals & Winter cereals & 20 & 995 \\
\hline thiencarbazone-methyl & 2016 & $\begin{array}{c}\text { Conviso One, Monsoon Active, Cossack } \\
\text { Star, Atlantis Star, Capreno }\end{array}$ & Maize, Beets, Cereals & Maize & 11.6 & 100 \\
\hline acibenzolar-S-methyl* & 2015 & Inssimo & Chrysanthemum & $\begin{array}{l}\text { Vegetables - } \\
\text { leafy }\end{array}$ & 0.131 & 1284 \\
\hline Penflufen & 2015 & $\begin{array}{c}\text { Emesto Prime DS, Emesto Prime } \\
\text { Vloeibaar, Emesto Silver, Emesto Silver } \\
\text { - rood }\end{array}$ & Potatoes & Potatoes & 113 & 483 \\
\hline penthiopyrad & 2015 & $\begin{array}{l}\text { DuPont CIELEX, DuPont FONTELIS } \\
\text { DuPont TREORIS DuPont VERTISAN }\end{array}$ & Cereals, Apple, Pear & $\begin{array}{l}\text { Spring cereals, } \\
\text { Pome fruit }\end{array}$ & 116.2 & 761 \\
\hline flupyrsulfuron-methyl & 2015 & DuPont LEXUS SX & Cereals & Winter cereals & 16.1 & 29.5 \\
\hline Benfluralin & 2014 & BONALAN & Beans, Peas & $\begin{array}{l}\text { Field beans, } \\
\text { Vegetables - } \\
\text { leafy, } \\
\text { Vegetables - } \\
\text { root }\end{array}$ & 38.7 & 10052 \\
\hline clethodim & 2014 & $\begin{array}{c}\text { Centurion Plus, WOPRO-Clethodim } 120 \\
\mathrm{gr} / \mathrm{lt}\end{array}$ & Beets, Potatoes & $\begin{array}{l}\text { Sugarbeet, } \\
\text { Potatoes }\end{array}$ & 0.66 & 4.0 \\
\hline Fenpyrazamine* & 2014 & Prolectus & Strawberries & $\begin{array}{l}\text { Vegetables - } \\
\text { fruiting }\end{array}$ & 20.5 & 310 \\
\hline imazamox & 2014 & Corum & Beans, Peas & Legumes & 45.6 & 67 \\
\hline napropamide* & 2014 & DEVRINOL 45SC & $\begin{array}{l}\text { Heading cabbages, Brussels sprouts, } \\
\text { cauliflower and broccoli }\end{array}$ & $\begin{array}{l}\text { Vegetables - } \\
\text { leafy }\end{array}$ & 19 & 648 \\
\hline thifensulfuron-methyl & 2014 & Harmony SX, Omnera & Maize, Grass & $\begin{array}{l}\text { Maize, } \\
\text { Grass/alfalfa }\end{array}$ & 3.4 & 28 \\
\hline
\end{tabular}

*active substance not included in the simulations because no authorized use in one of the six crops with the highest acreage in the intake area of the surface water abstraction points for drinking water 


\section{Results \& discussion}

In Table 3, the maximum concentration in the FOCUS D3 ditch (PEC $\mathrm{max}_{\text {) }}$ with Dutch drift deposition for the old and the new suite have been reported. The PEC $\max$ value is the starting point for the calculation of the concentration in the drinking water abstraction points (PEC_Tier1), that are located more downstream in larger water bodies. In Table 4, corresponding PEC_Tier1 values are reported. In Appendix 1, the use pattern, drift values and substance input parameters used for the model runs are reported.

Table 3 Maximum concentration (PEC $\max$ ) and cause of peaks in FOCUS D3 ditch for all model runs of the old and new suite.

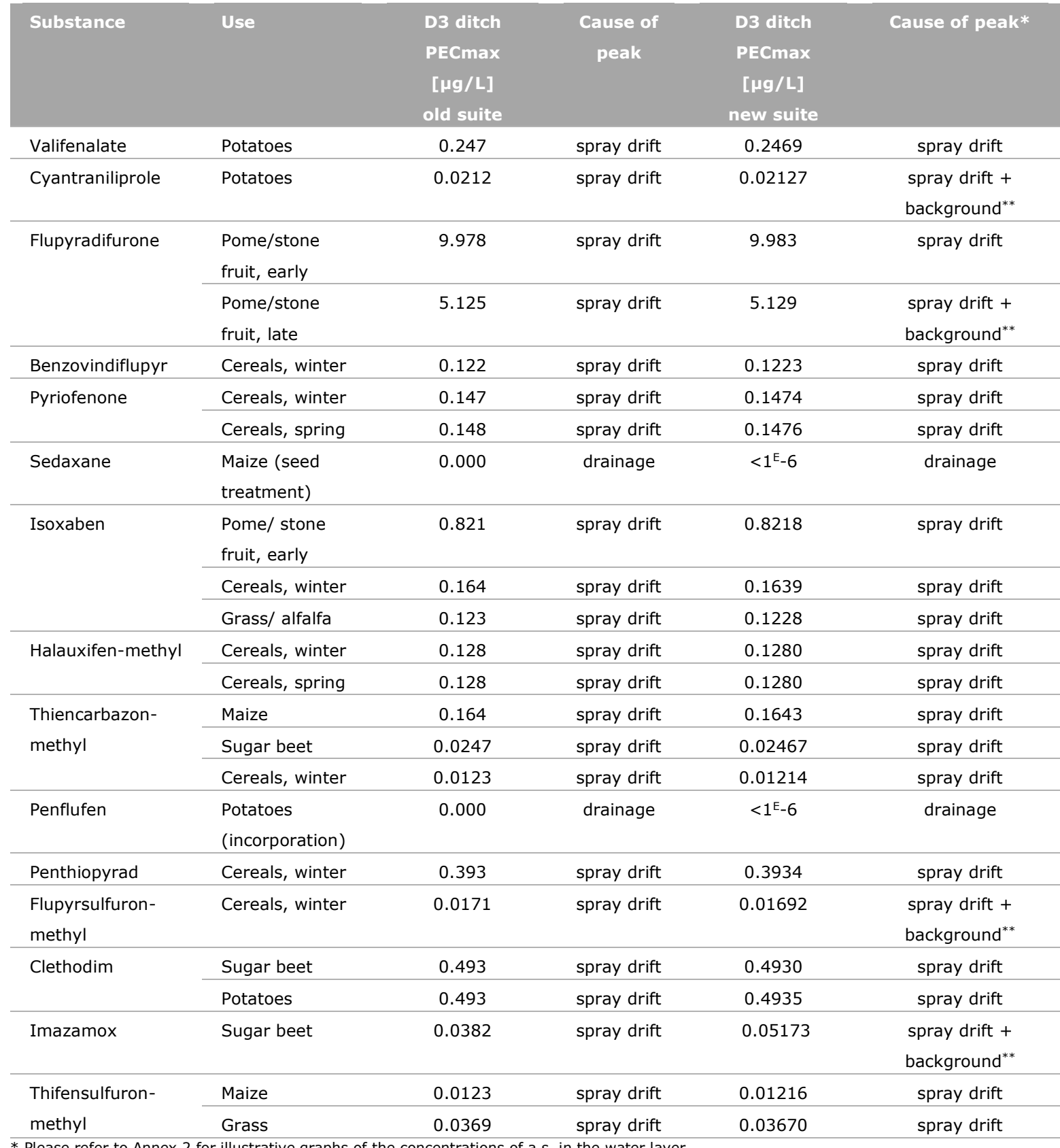

* Please refer to Annex 2 for illustrative graphs of the concentrations of a.s. in the water layer

$* *$ peak concentration due to spray drift occurs on top of a background concentration already present in the water layer

The results of the calculations performed with current and new FOCUS-SWASH versions show that the resulting FOCUS_NL D3 PEC $\max$ concentrations are only slightly different. Only application of imazamox 
in sugar beet results in a 1.5 times higher FOCUS_NL D3 PEC $\max$ concentration $(0.0382 \mu \mathrm{g} / \mathrm{L}$ vs $0.05173 \mu \mathrm{g} / \mathrm{L}$ for old and new suite, respectively). This increase is caused by an increase in the contribution of the existing background concentration in the water phase to the maximum concentration. For both suites, the maximum simulated concentration coincides with the time of application. According to the current Guidance (Van Leerdam et al., 2010), this suggests that the maximum concentration is caused by spray drift. However, for imazamox there is a significant contribution from the background concentration in the water phase to the maximum concentration. In Figure 2, the simulated concentration in the water phase is presented for both the old and new model suite. For the old model suite, about one third of the maximum concentration is caused by the existing background concentration; but for the new model suite about one half of the maximum concentration is caused by the existing background concentration. This increase in the simulated background concentration in the new model suite can be explained by the higher drainage flux that is calculated by the new FOCUS-MACRO version 5.5.3.

PEC_Tier1 results following calculations at the nine drinking water abstraction points, performed with

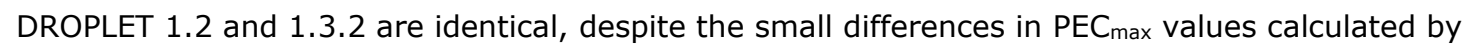
FOCUS-TOXSWA. The PEC_Tier1 is $<0.1 \mu \mathrm{g} / \mathrm{L}$ for all products for all abstraction points for the old and the new model suite.

Comparing our results to those of the WOt-technical report 100 we observe the following differences:

i. in this impact analysis the differences between the PEC max values in the D3 ditch of the old and the new model suite are clearly smaller than in the WOt-technical report 100 study, and;

ii. $\quad$ in this impact analysis the PEC_Tier1 values in the nine drinking water abstraction points are well below the threshold value of $0.1 \mu \mathrm{g} / \mathrm{L}$ for all 24 substance-crop combinations, while in the WOt-technical report 100 study the PEC_Tier1 values in the nine drinking water abstraction points are clearly above the threshold value of $0.1 \mu \mathrm{g} / \mathrm{L}$ for a number of substances (i.e. D, G and $\mathrm{H}$ ).

The reasons for these differences are:

i. the present impact analysis uses actual application rates, ranging between 0.01 to $0.1 \mathrm{~kg} / \mathrm{ha}$, while in the former WOt-technical report 100 the application rate was $1 \mathrm{~kg} / \mathrm{ha}$ for all substances, i.e. a factor 10 to 100 larger (thus leading to concentrations PECmax and PEC_Tier1 of a factor 10 to 100 smaller in the impact analysis);

ii. the 15 substances of the impact analysis are less sensitive to leaching via drains to surface water than substances $\mathrm{D}, \mathrm{G}$ and even $\mathrm{H}$ and thus lead to lower concentrations in surface water, PEC max as well as next, PEC_Tier1. (N.B. Note that substances D, G and H are very sensitive to leaching to drains because of a low sorption coefficient $K_{\text {oc }}$ of $10 \mathrm{~L} / \mathrm{kg}$ ( $D$ and $G$ ) or due to a combination of relatively low $\mathrm{K}_{\mathrm{oc}}$ of $100 \mathrm{~L} / \mathrm{kg}$ coupled to a long half-life in soil of 300 $\mathrm{d}(\mathrm{H}))$;

iii. due to their lower sensitivity for leaching to drains the peak concentration in the D3 ditch of the impact analysis is nearly always caused by spray drift deposition onto the D3 ditch. In this impact analysis a drift deposition percentage of 0.5 is used, while in the WOt-technical report 100 a percentage of 1 was used, i.e. twice as large. So, for substances where spray drift deposition caused the peak concentration in the D3 ditch in both studies, the impact analysis led to lower concentrations than the WOt-technical report 100 study. 


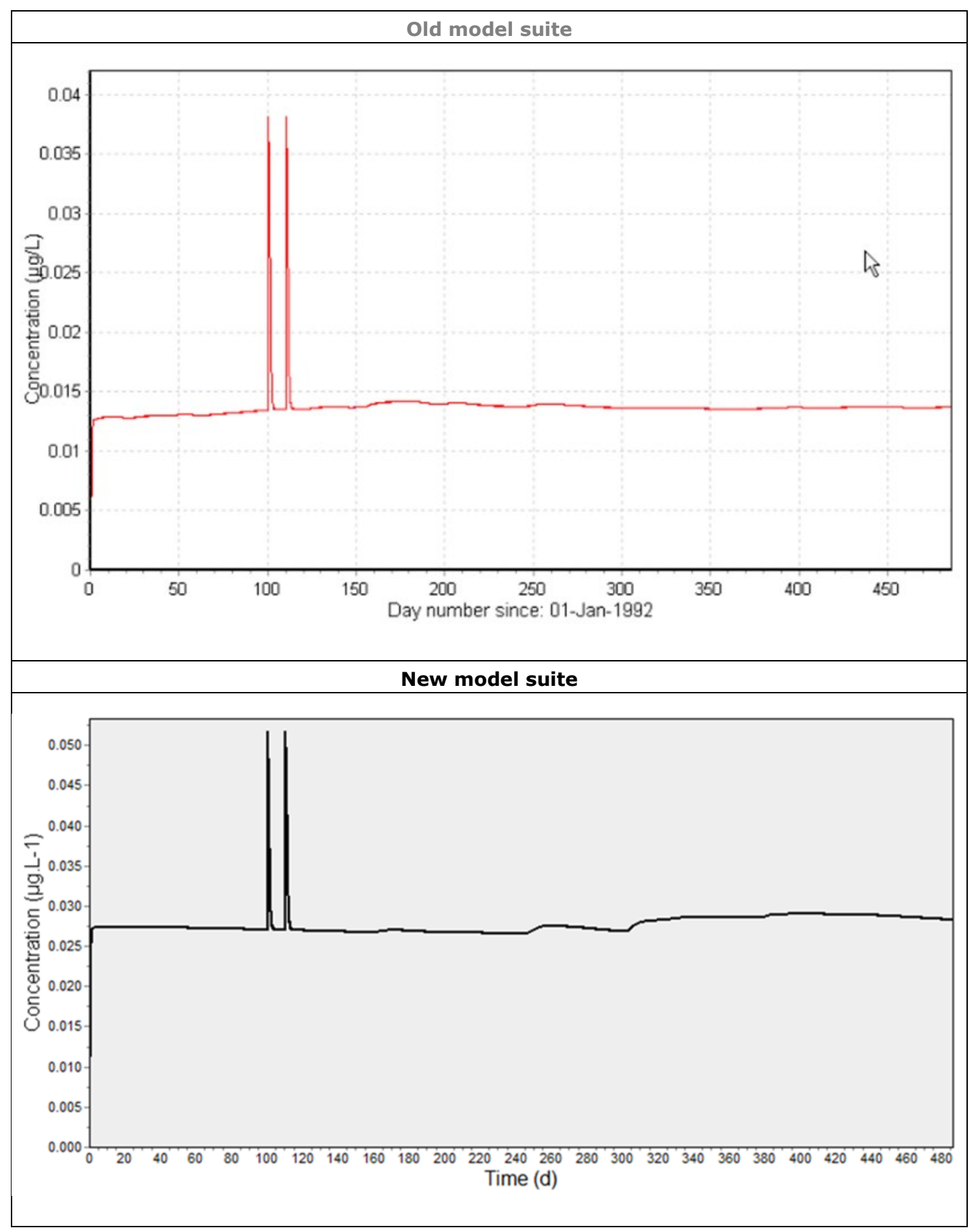

Figure 2 Total concentration in the water layer for the simulation of substance imazamox for both the old model suite (top) and the new model suite (bottom). 
Table 4 DROPLET values for various active substances.

\begin{tabular}{|c|c|c|c|c|c|c|c|c|c|c|c|c|c|c|}
\hline \multirow{5}{*}{$\begin{array}{l}\text { Drinking } \\
\text { water inlet } \\
\text { point }\end{array}$} & \multirow{2}{*}{\multicolumn{2}{|c|}{$\begin{array}{c}\text { Valifenalate } \\
\text { Potatoes }\end{array}$}} & \multirow{2}{*}{\multicolumn{2}{|c|}{$\begin{array}{c}\text { Cyantraniliprole } \\
\text { Potatoes }\end{array}$}} & \multicolumn{4}{|c|}{ Flupyradifurone } & \multirow{2}{*}{\multicolumn{2}{|c|}{$\begin{array}{l}\text { Benzovindiflupyr } \\
\text { Cereals, winter }\end{array}$}} & \multicolumn{4}{|c|}{ Pyriofenone } \\
\hline & & & & & \multirow{2}{*}{\multicolumn{2}{|c|}{$\begin{array}{l}\text { Pome/stone fruit, } \\
\text { early } \\
\text { PEC TIER 1 [ } \mu \mathrm{g} / \mathrm{L}]\end{array}$}} & \multirow{2}{*}{\multicolumn{2}{|c|}{$\begin{array}{c}\text { Pome/stone fruit, } \\
\text { late } \\
\text { PEC TIER } 1[\mu \mathrm{g} / \mathrm{L}]\end{array}$}} & & & \multicolumn{2}{|c|}{ Cereals, winter } & \multicolumn{2}{|c|}{ Cereals, spring } \\
\hline & \multicolumn{2}{|c|}{ PEC TIER 1 [ $\mu \mathrm{g} / \mathrm{L}]$} & \multicolumn{2}{|c|}{ PEC TIER $1[\mu \mathrm{g} / \mathrm{L}]$} & & & & & \multicolumn{2}{|c|}{ PEC TIER $1[\mu \mathrm{g} / \mathrm{L}]$} & \multicolumn{2}{|c|}{ PEC } & \multicolumn{2}{|c|}{ PECTIER 1 [ $\mu \mathrm{g} / \mathrm{L}]$} \\
\hline & DROPLET & DROPLET & DROPLET & DROPLET & \multicolumn{2}{|c|}{ DROPLET $\quad$ DROPLET } & \multicolumn{2}{|c|}{$\begin{array}{l}\text { PECLTIER 1 [Pg/L] } \\
\text { DROPLET DROPLET }\end{array}$} & DROPLET & DROPLET & DROPLET & DROPLET & DROPLET & DROPLET \\
\hline & 1.2 & 1.3 .2 & 1.2 & 1.3 .2 & 1.2 & 1.3 .2 & 1.2 & 1.3 .2 & 1.2 & 1.3 .2 & 1.2 & 1.3 .2 & 1.2 & 1.3 .2 \\
\hline De Punt & 0.001 & 0.001 & 0.000 & 0.000 & 0.000 & 0.000 & 0.000 & 0.000 & 0.001 & 0.001 & 0.001 & 0.001 & 0.001 & 0.001 \\
\hline Andijk & 0.000 & 0.000 & 0.000 & 0.000 & 0.000 & 0.000 & 0.000 & 0.000 & 0.000 & 0.000 & 0.000 & 0.000 & 0.000 & 0.000 \\
\hline Nieuwegein & 0.000 & 0.000 & 0.000 & 0.000 & 0.031 & 0.031 & 0.016 & 0.016 & 0.000 & 0.000 & 0.001 & 0.001 & 0.001 & 0.001 \\
\hline Heel & 0.000 & 0.000 & 0.000 & 0.000 & 0.013 & 0.013 & 0.007 & 0.007 & 0.001 & 0.001 & 0.001 & 0.001 & 0.001 & 0.001 \\
\hline $\begin{array}{l}\text { Amsterdam- } \\
\text { Rijnkanaal }\end{array}$ & 0.000 & 0.000 & 0.000 & 0.000 & 0.024 & 0.024 & 0.012 & 0.012 & 0.000 & 0.000 & 0.000 & 0.000 & 0.000 & 0.000 \\
\hline Brakel & 0.000 & 0.000 & 0.000 & 0.000 & 0.005 & 0.005 & 0.002 & 0.002 & 0.000 & 0.000 & 0.000 & 0.000 & 0.001 & 0.001 \\
\hline Petrusplaat & 0.000 & 0.000 & 0.000 & 0.000 & 0.004 & 0.004 & 0.002 & 0.002 & 0.000 & 0.000 & 0.000 & 0.000 & 0.000 & 0.000 \\
\hline Twentekanaal & 0.000 & 0.000 & 0.000 & 0.000 & 0.000 & 0.000 & 0.000 & 0.000 & 0.000 & 0.000 & 0.000 & 0.000 & 0.000 & 0.000 \\
\hline Scheelhoek & 0.000 & 0.000 & 0.000 & 0.000 & 0.010 & 0.010 & 0.005 & 0.005 & 0.001 & 0.001 & 0.001 & 0.001 & 0.001 & 0.001 \\
\hline Bommelerwaard & 0.000 & 0.000 & 0.000 & 0.000 & 0.027 & 0.027 & 0.014 & 0.014 & 0.000 & 0.000 & 0.000 & 0.000 & 0.000 & 0.000 \\
\hline \multirow{5}{*}{$\begin{array}{l}\text { Drinking } \\
\text { water inlet } \\
\text { point }\end{array}$} & \multicolumn{2}{|c|}{ Sedaxane } & \multicolumn{6}{|c|}{ Isoxaben } & \multicolumn{4}{|c|}{ Halauxifen-methyl } & \multicolumn{2}{|c|}{$\begin{array}{c}\text { Thiencarbazon- } \\
\text { methyl }\end{array}$} \\
\hline & \multicolumn{2}{|c|}{$\begin{array}{l}\text { Maize (seed } \\
\text { treatment) }\end{array}$} & \multicolumn{2}{|c|}{$\begin{array}{l}\text { Pome/stone fruit, } \\
\text { early }\end{array}$} & \multicolumn{2}{|c|}{ Cereals, winter } & \multicolumn{2}{|c|}{ Grass/ alfalfa } & Cerea & winter & Cerea & spring & & \\
\hline & PEC & [ $\mu \mathrm{g} / \mathrm{L}]$ & $\mathrm{PEC}_{\mathrm{TI}}$ & 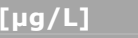 & PEC & 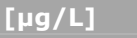 & PEC & [ $\mu \mathrm{g} / \mathrm{L}]$ & PEC & 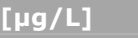 & PEC & {$[\mu \mathrm{g} / \mathrm{L}$} & PECTIE & 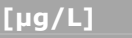 \\
\hline & DROPLET & DROPLET & DROPLET & DROPLET & DROPLET & DROPLET & DROPLET & DROPLET & DROPLET & DROPLET & DROPLET & DROPLET & DROPLET & DROPLET \\
\hline & 1.2 & 1.3 .2 & 1.2 & 1.3 .2 & 1.2 & 1.3 .2 & 1.2 & 1.3 .2 & 1.2 & 1.3 .2 & 1.2 & 1.3 .2 & 1.2 & 1.3 .2 \\
\hline De Punt & 0.000 & 0.000 & 0.000 & 0.000 & 0.001 & 0.001 & 0.003 & 0.003 & 0.000 & 0.000 & 0.000 & 0.000 & 0.001 & 0.001 \\
\hline Andijk & 0.000 & 0.000 & 0.000 & 0.000 & 0.000 & 0.000 & 0.001 & 0.001 & 0.000 & 0.000 & 0.000 & 0.000 & 0.000 & 0.000 \\
\hline Nieuwegein & 0.000 & 0.000 & 0.003 & 0.003 & 0.001 & 0.001 & 0.004 & 0.004 & 0.000 & 0.000 & 0.000 & 0.000 & 0.001 & 0.001 \\
\hline Heel & 0.000 & 0.000 & 0.001 & 0.001 & 0.001 & 0.001 & 0.002 & 0.002 & 0.000 & 0.000 & 0.000 & 0.000 & 0.001 & 0.001 \\
\hline $\begin{array}{l}\text { Amsterdam- } \\
\text { Rijnkanaal }\end{array}$ & 0.000 & 0.000 & 0.002 & 0.002 & 0.001 & 0.001 & 0.004 & 0.004 & 0.000 & 0.000 & 0.000 & 0.000 & 0.001 & 0.001 \\
\hline Brakel & 0.000 & 0.000 & 0.000 & 0.000 & 0.001 & 0.001 & 0.002 & 0.002 & 0.000 & 0.000 & 0.000 & 0.000 & 0.002 & 0.002 \\
\hline Petrusplaat & 0.000 & 0.000 & 0.000 & 0.000 & 0.001 & 0.001 & 0.002 & 0.002 & 0.000 & 0.000 & 0.000 & 0.000 & 0.002 & 0.002 \\
\hline Twentekanaal & 0.000 & 0.000 & 0.000 & 0.000 & 0.000 & 0.000 & 0.003 & 0.003 & 0.000 & 0.000 & 0.000 & 0.000 & 0.001 & 0.001 \\
\hline Scheelhoek & 0.000 & 0.000 & 0.001 & 0.001 & 0.001 & 0.001 & 0.003 & 0.003 & 0.000 & 0.000 & 0.000 & 0.000 & 0.002 & 0.002 \\
\hline Bommelerwaard & 0.000 & 0.000 & 0.002 & 0.002 & 0.000 & 0.000 & 0.005 & 0.005 & 0.000 & 0.000 & 0.000 & 0.000 & 0.001 & 0.001 \\
\hline
\end{tabular}


(continued).

\begin{tabular}{|c|c|c|c|c|c|c|c|c|c|c|c|c|c|c|}
\hline \multirow{5}{*}{$\begin{array}{l}\text { Drinking } \\
\text { water inlet } \\
\text { point }\end{array}$} & \multicolumn{4}{|c|}{ Thiencarbazon-methyl } & \multicolumn{2}{|c|}{ Penflufen } & \multicolumn{2}{|c|}{ Penthiopyrad } & \multirow{2}{*}{\multicolumn{2}{|c|}{$\begin{array}{c}\begin{array}{c}\text { Flupyrsulfuron- } \\
\text { methyl }\end{array} \\
\text { Cereals, winter }\end{array}$}} & \multicolumn{4}{|c|}{ Clethodim } \\
\hline & \multicolumn{2}{|c|}{ Sugar beet } & \multicolumn{2}{|c|}{ Cereals, winter } & \multicolumn{2}{|c|}{$\begin{array}{c}\text { Potatoes } \\
\text { (incorporation) }\end{array}$} & \multicolumn{2}{|c|}{ Cereals, winter } & & & \multicolumn{2}{|c|}{ Sugar beet } & \multicolumn{2}{|c|}{ Potatoes } \\
\hline & \multicolumn{2}{|c|}{ PEC $_{\text {TIER } 1}[\mathrm{\mu g} / \mathrm{L}]$} & \multicolumn{2}{|c|}{ PEC TIER $1[\mu \mathrm{g} / \mathrm{L}]$} & \multicolumn{2}{|c|}{ PEC $_{\text {TIER } 1}[\mu \mathrm{g} / \mathrm{L}]$} & \multicolumn{2}{|c|}{ PEC $_{\text {TIER } 1}[\mu \mathrm{g} / \mathrm{L}]$} & \multicolumn{2}{|c|}{$\operatorname{PEC}_{\text {TIER } 1}[\mu \mathrm{g} / \mathrm{L}]$} & \multicolumn{2}{|c|}{$\operatorname{PEC}_{\text {TIER } 1}[\mu \mathrm{g} / \mathrm{L}]$} & \multicolumn{2}{|c|}{ PEC TIER $1[\mu \mathrm{g} / \mathrm{L}]$} \\
\hline & DROPLET & DROPLET & DROPLET & DROPLET & DROPLET & DROPLET & DROPLET & DROPLET & DROPLET & DROPLET & DROPLET & DROPLET & DROPLET & DROPLET \\
\hline & 1.2 & 1.3 .2 & 1.2 & 1.3 .2 & 1.2 & 1.3 .2 & 1.2 & 1.3 .2 & 1.2 & 1.3 .2 & 1.2 & 1.3 .2 & 1.2 & 1.3 .2 \\
\hline De Punt & 0.000 & 0.000 & 0.000 & 0.000 & 0.000 & 0.000 & 0.002 & 0.002 & 0.000 & 0.000 & 0.001 & 0.001 & 0.004 & 0.004 \\
\hline Andijk & 0.000 & 0.000 & 0.000 & 0.000 & 0.000 & 0.000 & 0.000 & 0.000 & 0.000 & 0.000 & 0.000 & 0.000 & 0.000 & 0.000 \\
\hline Nieuwegein & 0.000 & 0.000 & 0.000 & 0.000 & 0.000 & 0.000 & 0.001 & 0.001 & 0.000 & 0.000 & 0.000 & 0.000 & 0.000 & 0.000 \\
\hline Heel & 0.000 & 0.000 & 0.000 & 0.000 & 0.000 & 0.000 & 0.003 & 0.003 & 0.000 & 0.000 & 0.002 & 0.002 & 0.001 & 0.001 \\
\hline $\begin{array}{l}\text { Amsterdam- } \\
\text { Rijnkanaal }\end{array}$ & 0.000 & 0.000 & 0.000 & 0.000 & 0.000 & 0.000 & 0.001 & 0.001 & 0.000 & 0.000 & 0.000 & 0.000 & 0.000 & 0.000 \\
\hline Brakel & 0.000 & 0.000 & 0.000 & 0.000 & 0.000 & 0.000 & 0.001 & 0.001 & 0.000 & 0.000 & 0.001 & 0.001 & 0.001 & 0.001 \\
\hline Petrusplaat & 0.000 & 0.000 & 0.000 & 0.000 & 0.000 & 0.000 & 0.001 & 0.001 & 0.000 & 0.000 & 0.001 & 0.001 & 0.001 & 0.001 \\
\hline Twentekanaal & 0.000 & 0.000 & 0.000 & 0.000 & 0.000 & 0.000 & 0.000 & 0.000 & 0.000 & 0.000 & 0.000 & 0.000 & 0.000 & 0.000 \\
\hline Scheelhoek & 0.000 & 0.000 & 0.000 & 0.000 & 0.000 & 0.000 & 0.001 & 0.001 & 0.000 & 0.000 & 0.001 & 0.001 & 0.001 & 0.001 \\
\hline Bommelerwaard & 0.000 & 0.000 & 0.000 & 0.000 & 0.000 & 0.000 & 0.001 & 0.001 & 0.000 & 0.000 & 0.000 & 0.000 & 0.000 & 0.000 \\
\hline \multirow{5}{*}{$\begin{array}{l}\text { Drinking } \\
\text { water inlet } \\
\text { point }\end{array}$} & \multicolumn{2}{|c|}{ Imazamox } & \multicolumn{4}{|c|}{ Thifensulfuron-methyl } & & & & & & & & \\
\hline & \multicolumn{2}{|c|}{ Sugar beet } & \multicolumn{2}{|c|}{ Maize } & \multicolumn{2}{|c|}{ Grass } & & & & & & & & \\
\hline & \multicolumn{2}{|c|}{ PEC $_{\text {TIER } 1}[\mu \mathrm{g} / \mathrm{L}]$} & \multicolumn{2}{|c|}{$\mathrm{PEC}_{\mathrm{TIER} 1}[\mu \mathrm{g} / \mathrm{L}$} & PEC $_{\text {TIE }}$ & {$[\mu \mathrm{g} / \mathrm{L}$} & & & & & & & & \\
\hline & DROPLET & DROPLET & DROPLET & DROPLET & DROPLET & DROPLET & & & & & & & & \\
\hline & 1.2 & 1.3 .2 & 1.2 & 1.3 .2 & 1.2 & 1.3 .2 & & & & & & & & \\
\hline De Punt & 0.000 & 0.000 & 0.000 & 0.000 & 0.000 & 0.000 & & & & & & & & \\
\hline Andijk & 0.000 & 0.000 & 0.000 & 0.000 & 0.000 & 0.000 & & & & & & & & \\
\hline Nieuwegein & 0.000 & 0.000 & 0.000 & 0.000 & 0.000 & 0.000 & & & & & & & & \\
\hline Heel & 0.001 & 0.001 & 0.000 & 0.000 & 0.000 & 0.000 & & & & & & & & \\
\hline $\begin{array}{l}\text { Amsterdam- } \\
\text { Rijnkanaal }\end{array}$ & 0.000 & 0.000 & 0.000 & 0.000 & 0.000 & 0.000 & & & & & & & & \\
\hline Brakel & 0.000 & 0.000 & 0.000 & 0.000 & 0.000 & 0.000 & & & & & & & & \\
\hline Petrusplaat & 0.000 & 0.000 & 0.000 & 0.000 & 0.000 & 0.000 & & & & & & & & \\
\hline Twentekanaal & 0.000 & 0.000 & 0.000 & 0.000 & 0.000 & 0.000 & & & & & & & & \\
\hline Scheelhoek & 0.000 & 0.000 & 0.000 & 0.000 & 0.000 & 0.000 & & & & & & & & \\
\hline Bommelerwaard & 0.000 & 0.000 & 0.000 & 0.000 & 0.001 & 0.001 & & & & & & & & \\
\hline
\end{tabular}





\section{Conclusions and recommendations}

The impact analysis has demonstrated that for the plant protection products which have been authorized in the period 2014 - 2018, for which the current version of DROPLET (1.2) was used in the risk assessment, the use of the new DROPLET version (1.3.2.) has no effect on the conclusion for the drinking water criterion. The PEC_Tier1 is $<0.1 \mu \mathrm{g} / \mathrm{L}$ for all products for all abstraction points for both the old and the new model suite.

In WOt-technical report 100 (Adriaanse \& Beltman, 2017) calculations were made with hypothetical substances and hypothetical application rates. In this impact analyses calculations were based on existing plant protection products, with a factor 10 to 100 lower application rates $(0.01$ to $0.1 \mathrm{~kg} / \mathrm{ha}$ vs $1 \mathrm{~kg} / \mathrm{ha}$ ) and substances which are less sensitive to leaching via drainage. Apparently, the application rate of $1 \mathrm{~kg} / \mathrm{ha}$ and the specific substance properties of the hypothetical substances used in Adriaanse \& Beltman (2017), are not likely to occur in 'real' plant protection products. The only product that contained an active substance with these properties (i.e. imazamox), is not used in the high dose rate $(1 \mathrm{~kg} / \mathrm{ha})$ that was used in the calculations by Adriaanse \& Beltman (2017). Therefore, in this impact study the PEC_Tier1 values in the nine drinking water abstraction points are well below the threshold value of $0.1 \mu \mathrm{g} / \mathrm{L}$ for all 24 substance-crop combinations, while in the WOt-technical report 100 study, the PEC_Tier1 values in the nine drinking water abstraction points are clearly above the threshold value of $0.1 \mu \mathrm{g} / \mathrm{L}$ for a number of substances (i.e. D, G and $\mathrm{H}$ ).

So, the overall conclusion is that the study of the WOt-technical report 100 led to overly conservative concentrations in the drinking water abstraction points, as demonstrated by the results of the more realistic calculations of the present impact study.

Based on the impact analysis, it can be concluded that implementation of new DROPLET model version, to be used in collaboration with the newer release of the FOCUS models, is not expected to have a significant impact on the risk assessment of 'real' plant protection products regarding the drinking water criterion.

Adriaanse \& Beltman (2017) showed that the latest version of the FOCUS model MACRO (version 5.5.3), calculates higher drainage fluxes for the FOCUS D3 scenario compared to the old MACRO (version 4.4.2). At present it is unclear which version of MACRO results in drainage fluxes reflecting best reality for the D3 scenario. Therefore, Adriaanse \& Beltman (2017) concluded that it is not possible to make any recommendation on the preferred model suite for use in the exposure assessment procedure at EU level and in The Netherlands. However, the presented impact analysis has shown that it is not expected that the use of the new DROPLET version in combination with MACRO 5.5.3 will have a significant impact on the risk assessment.

In addition, applicants are required to use the newest version of the FOCUS surface water models in the zonal submission of an application for authorization of a plant protection product. The use of MACRO version 4.4.2 is no longer allowed in a zonal surface water assessment at EU level. The new DROPLET version facilitates the national risk assessment for the drinking water criterion, because it can be used in combination with the new FOCUS models. Therefore, applicants will no longer need to revert to older versions of the FOCUS models to be able to perform the national risk assessment for the drinking water criterion, when applying for authorization of a product in the Netherlands.

So, both based upon the fact that the impact study revealed that there is no influence on the concentrations at the drinking water abstraction points by updating from the DROPLET 1.2 to DROPLET 1.3.2 model suite and the fact that use of MACRO 4.4.2 of the old DROPLET suite is no longer allowed in a zonal surface water assessment, we recommend implementing the new DROPLET version in the national authorization procedure. 



\section{References}

Adriaanse, P.I. and W.H.J. Beltman (2017). Comparison of pesticide concentrations at drinking water abstraction points in The Netherlands simulated by DROPLET version 1.2 and 1.3.2 model suites. Wageningen, the Statutory Research Tasks Unit for Nature \& the Environment (WOT Natuur \& Milieu). WOt-technical report 100. 52 p.; 6 Figs; 12 Tabs; 5 Refs; 5 Annexes.

Ctgb (2018). Evaluation Manual for the Authorisation of Plant protection products and Biocides according to Regulation (EC) No 1107/2009 NL part Plant protection products Chapter 6 Fate and behaviour in the environment; behaviour in surface water and sediment.

Van Kraalingen, D., E.L. Wipfler, F. van den Berg, W.H.J. Beltman, M.S. ter Horst, G. Fait, J.A. te Roller (2013). SPIN Manual 1.1. User's Guide version 1, for use with FOCUS_SWASH 4.2. WOt-werkdocument 354. WOT Natuur \& Milieu, Wageningen UR, Wageningen, The Netherlands.

Van Leerdam, R.C., P.I. Adriaanse and J.A. te Roller (2010). DROPLET to calculate concentrations at drinking water abstraction points. Alterra report 2020. 



\section{List of used abbreviations}

Variable

PECmax

PEC_Tier1

\section{Description}

Maximum Predicted Environmental Concentration in

water of the FOCUS D3 ditch receiving spray drift

deposition according to Dutch deposition numbers

Predicted Environmental Concentration at the surface

water abstraction points for drinking water production 



\section{Justification}

This study was carried out by ir. A. de Jong and drs. A. Poot, (Ctgb, Dutch Board for the Authorisation of Plant Protection Products and Biocides), and supervised by dr. Erik van den Berg and ir. Paulien Adriaanse (Wageningen Environmental Research, Wageningen University and Research). Critical questions and remarks by drs. Miranda Meijster (Ministry of Agriculture, Nature and Food Quality) to an early version of this report, have contributed to a more accessible final report. 



\section{Annex 1 Substance input parameters and model input parameters}

\begin{tabular}{|c|c|c|c|c|c|c|c|}
\hline Substance & Product & D3 Use & $\begin{array}{c}\text { Droplet } \\
\text { Crop }\end{array}$ & $\begin{array}{c}\text { Freq./ } \\
\text { interv } \\
\text { al }\end{array}$ & $\begin{array}{c}\text { Dose } \\
\text { rate } \\
\text { [kg/h } \\
\text { a] }\end{array}$ & $\begin{array}{c}\text { MACR } \\
0 \\
\text { Julian } \\
\text { days }\end{array}$ & $\begin{array}{c}\text { TOXS } \\
\text { WA } \\
\text { drift } \\
(\%)\end{array}$ \\
\hline Valifenalate & Valis M & Potatoes & Potatoes & $4 / 7$ & 0.150 & $\begin{array}{c}116- \\
180\end{array}$ & 0.5 \\
\hline \multicolumn{8}{|c|}{ Substance input parameters } \\
\hline \multicolumn{3}{|c|}{ Molecular mass } & \multicolumn{5}{|l|}{398.89} \\
\hline \multicolumn{3}{|c|}{ Saturated vapour pressure } & \multicolumn{5}{|l|}{$9.6 \mathrm{E}-8$} \\
\hline \multicolumn{3}{|c|}{ Solubility in water } & \multicolumn{5}{|l|}{45.5} \\
\hline \multicolumn{3}{|c|}{ Arithmetic mean Kom } & \multicolumn{5}{|l|}{498.3} \\
\hline \multicolumn{3}{|c|}{ Arithmetic mean $1 / \mathrm{n}$} & \multicolumn{5}{|l|}{1.038} \\
\hline \multicolumn{3}{|c|}{ Factor plant uptake } & \multicolumn{5}{|c|}{0.0 (conservative default) } \\
\hline \multicolumn{3}{|c|}{ Geometric mean $\mathrm{DT}_{50}$ water ( $\mathrm{DT}_{50}$ system) } & \multicolumn{5}{|c|}{4.6} \\
\hline \multicolumn{3}{|c|}{ Geometric mean field/lab DT $_{50}$ soil } & \multicolumn{5}{|l|}{0.15} \\
\hline \multicolumn{3}{|c|}{$\mathrm{DT}_{50}$ sediment } & \multicolumn{5}{|c|}{1000 (default) } \\
\hline \multicolumn{3}{|l|}{$\mathrm{DT}_{50} \operatorname{crop}(\mathrm{d})$} & \multicolumn{5}{|c|}{10 (default) } \\
\hline
\end{tabular}

\begin{tabular}{|c|c|c|c|c|c|c|c|}
\hline Substance & Product & D3 Use & $\begin{array}{c}\text { Droplet } \\
\text { Crop }\end{array}$ & $\begin{array}{l}\text { Freq./ } \\
\text { interval }\end{array}$ & $\begin{array}{c}\text { Dose } \\
\text { rate } \\
\text { [kg/ha] }\end{array}$ & $\begin{array}{l}\text { MACRO } \\
\text { Julian } \\
\text { days }\end{array}$ & $\begin{array}{c}\text { TOXSWA } \\
\text { drift } \\
(\%)\end{array}$ \\
\hline Cyantraniliprole & Benevia & Potatoes & Potatoes & $2 / 7$ & 0.0125 & $\begin{array}{c}116- \\
160 \\
\end{array}$ & 0.5 \\
\hline \multicolumn{8}{|c|}{ Substance input parameters } \\
\hline \multicolumn{3}{|c|}{ Molecular mass $(\mathrm{g} / \mathrm{mol})$} & \multicolumn{5}{|l|}{473.7} \\
\hline \multicolumn{3}{|c|}{ Saturated vapour pressure $(\mathrm{Pa})\left(20^{\circ} \mathrm{C}\right)$} & \multicolumn{5}{|l|}{$5.1 \mathrm{E}-15$} \\
\hline \multicolumn{3}{|c|}{ Solubility in water $(\mathrm{mg} / \mathrm{L})$} & \multicolumn{5}{|l|}{14.2} \\
\hline \multicolumn{3}{|c|}{ Arithmetic mean Kom $(\mathrm{mL} / \mathrm{g})$} & \multicolumn{5}{|l|}{112} \\
\hline \multicolumn{3}{|c|}{ Arithmetic mean $1 / \mathrm{n}$} & \multicolumn{5}{|l|}{0.93} \\
\hline \multicolumn{3}{|c|}{ Factor plant uptake } & \multicolumn{5}{|c|}{0.0 (conservative default) } \\
\hline \multicolumn{3}{|c|}{ Geometric mean $\mathrm{DT}_{50}$ water $\left(\mathrm{DT}_{50}\right.$ system) $(\mathrm{d})$} & \multicolumn{5}{|c|}{25.1} \\
\hline \multicolumn{3}{|c|}{ Geometric mean field/lab DT 50 soil (d) } & \multicolumn{5}{|l|}{87.0} \\
\hline \multicolumn{3}{|c|}{$\mathrm{DT}_{50}$ sediment $(\mathrm{d})$} & \multicolumn{5}{|c|}{1000 (default) } \\
\hline \multicolumn{3}{|l|}{$\mathrm{DT}_{50} \operatorname{crop}(\mathrm{d})$} & \multicolumn{5}{|c|}{10 (default) } \\
\hline
\end{tabular}




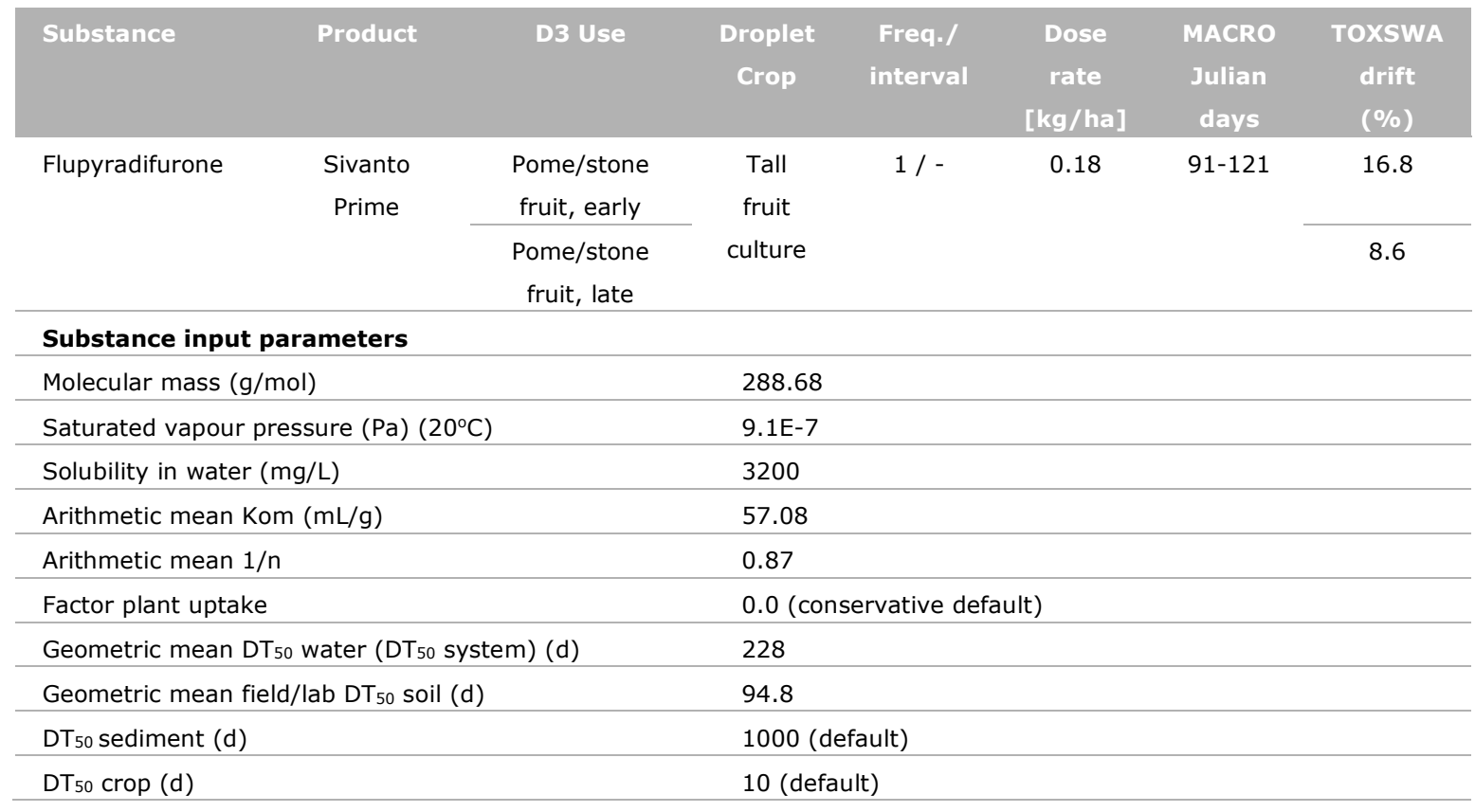

\begin{tabular}{|c|c|c|c|c|c|c|c|}
\hline Substance & Product & D3 Use & $\begin{array}{l}\text { Drople } \\
\text { t Crop }\end{array}$ & $\begin{array}{c}\text { Freq./ } \\
\text { interva } \\
\text { I }\end{array}$ & $\begin{array}{c}\text { Dose } \\
\text { rate } \\
\text { [kg/ha } \\
]\end{array}$ & $\begin{array}{c}\text { MACR } \\
0 \\
\text { Julian } \\
\text { days }\end{array}$ & $\begin{array}{c}\text { Toxsw } \\
\text { A drift } \\
(\%)\end{array}$ \\
\hline Benzovindiflupyr & Elatus Era & $\begin{array}{c}\text { Cereals, } \\
\text { winter }\end{array}$ & Cereals & $1 /-$ & 0.075 & $\begin{array}{l}311- \\
341\end{array}$ & 0.5 \\
\hline \multicolumn{8}{|c|}{ Substance input parameters } \\
\hline \multicolumn{3}{|c|}{ Molecular mass ( $\mathrm{g} / \mathrm{mol})$} & \multicolumn{5}{|l|}{398.24} \\
\hline \multicolumn{3}{|c|}{ Saturated vapour pressure $(\mathrm{Pa})\left(25^{\circ} \mathrm{C}\right)$} & \multicolumn{5}{|l|}{$3.2 \mathrm{E}-9$} \\
\hline \multicolumn{3}{|c|}{ Solubility in water $(\mathrm{mg} / \mathrm{L})\left(25^{\circ} \mathrm{C}\right)$} & \multicolumn{5}{|l|}{0.98} \\
\hline \multicolumn{3}{|c|}{ Arithmetic mean Kom $(\mathrm{mL} / \mathrm{g})$} & \multicolumn{5}{|l|}{2144} \\
\hline \multicolumn{3}{|c|}{ Geometric mean $\mathrm{DT}_{50}$ water $\left(\mathrm{DT}_{50}\right.$ system) (d) } & \multicolumn{5}{|c|}{1000 (default) } \\
\hline \multicolumn{3}{|c|}{ Geometric mean field/lab DT50 soil (d) } & \multicolumn{5}{|l|}{184} \\
\hline \multicolumn{3}{|l|}{$\mathrm{DT}_{50}$ sediment $(\mathrm{d})$} & \multicolumn{5}{|l|}{559} \\
\hline \multicolumn{3}{|l|}{$\mathrm{DT}_{50} \operatorname{crop}(\mathrm{d})$} & \multicolumn{5}{|c|}{10 (default) } \\
\hline
\end{tabular}




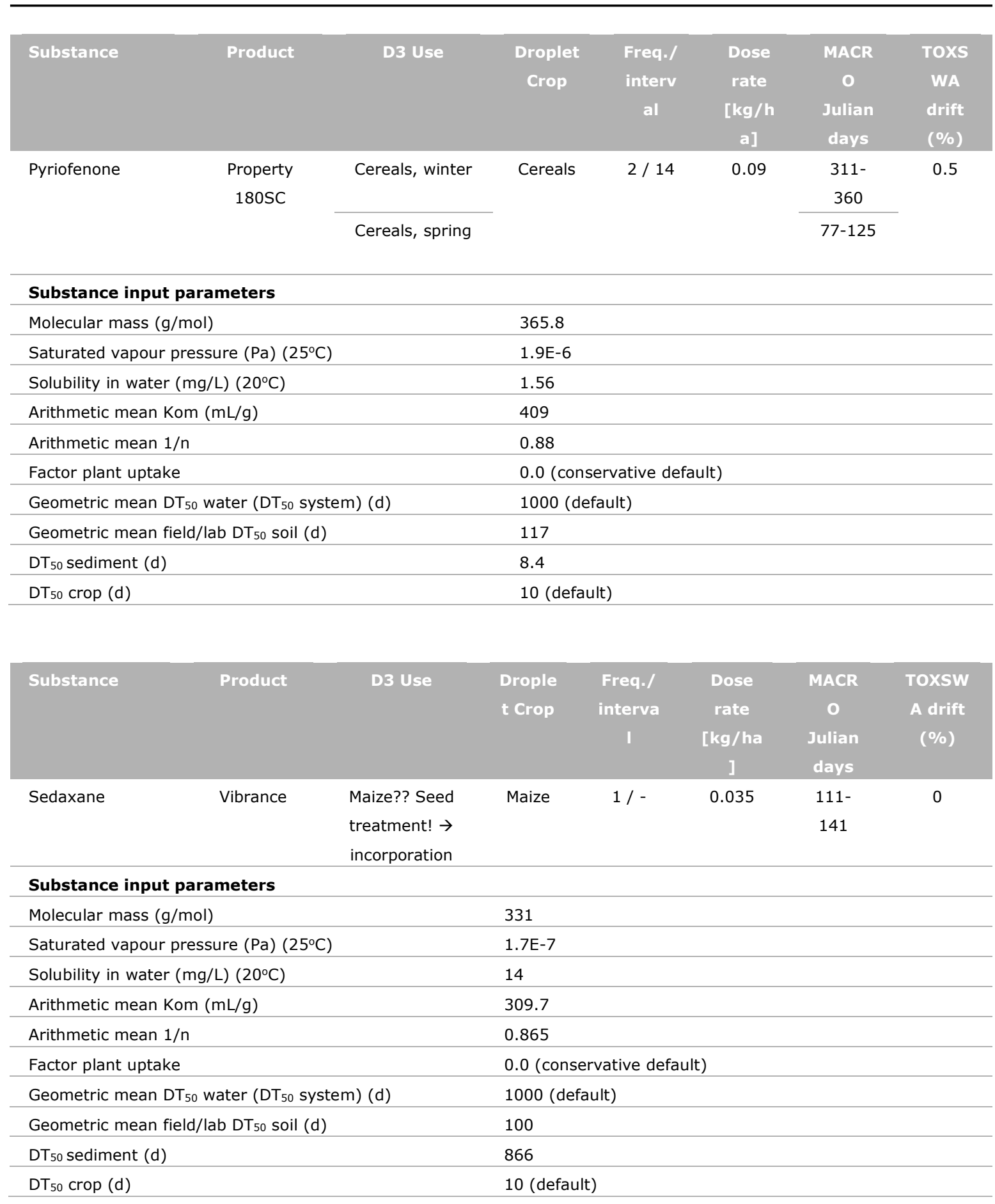




\begin{tabular}{|c|c|c|c|c|c|c|c|}
\hline Substance & Product & D3 Use & $\begin{array}{c}\text { Droplet } \\
\text { Crop }\end{array}$ & $\begin{array}{c}\text { Freq./ } \\
\text { interv } \\
\text { al }\end{array}$ & $\begin{array}{l}\text { Dose } \\
\text { rate } \\
\text { [kg/h } \\
\text { a] }\end{array}$ & $\begin{array}{c}\text { MACR } \\
0 \\
\text { Julian } \\
\text { days }\end{array}$ & $\begin{array}{l}\text { TOXS } \\
\text { WA } \\
\text { drift } \\
(\%)\end{array}$ \\
\hline \multirow[t]{3}{*}{ Isoxaben } & \multirow[t]{3}{*}{ AZ 500} & $\begin{array}{l}\text { Pome/stone } \\
\text { fruit, early } \\
\text { (herbicide } \\
\text { treatment) }\end{array}$ & $\begin{array}{l}\text { Tall fruit } \\
\text { culture }\end{array}$ & \multirow[t]{3}{*}{$1 /-$} & 0.5 & $91-121$ & \multirow[t]{3}{*}{0.5} \\
\hline & & Cereals, winter & Cereals & & 0.1 & $\begin{array}{l}311- \\
341\end{array}$ & \\
\hline & & Grass/ alfalfa & Grass & & 0.075 & $1-31$ & \\
\hline
\end{tabular}

\begin{tabular}{ll}
\hline Substance input parameters & \\
\hline Molecular mass $(\mathrm{g} / \mathrm{mol})$ & 332.4 \\
\hline Saturated vapour pressure $(\mathrm{Pa})\left(20^{\circ} \mathrm{C}\right)$ & $5.5 \mathrm{E}-7$ \\
\hline Solubility in water $(\mathrm{mg} / \mathrm{L})\left(20^{\circ} \mathrm{C}\right)$ & 1.04 \\
\hline Arithmetic mean $\mathrm{Kom}(\mathrm{mL} / \mathrm{g})$ & 205.3 \\
\hline Arithmetic mean $1 / \mathrm{n}$ & 0.905 \\
\hline Factor plant uptake & 0.0 (conservative default) \\
\hline Geometric mean DT50 water $\left(\mathrm{DT}_{50}\right.$ system) $(\mathrm{d})$ & 1000 (default) \\
\hline Geometric mean field/lab $\mathrm{DT}_{50}$ soil $(\mathrm{d})$ & 94.3 \\
\hline $\mathrm{DT}_{50}$ sediment $(\mathrm{d})$ & 16.8 \\
\hline $\mathrm{DT}_{50}$ crop $(\mathrm{d})$ & 10 (default) \\
\hline
\end{tabular}

\begin{tabular}{|c|c|c|c|c|c|c|c|}
\hline Substance & Product & D3 Use & $\begin{array}{c}\text { Droplet } \\
\text { Crop }\end{array}$ & $\begin{array}{c}\text { Freq./ } \\
\text { interv } \\
\text { al }\end{array}$ & $\begin{array}{c}\text { Dose } \\
\text { rate } \\
\text { [kg/h } \\
\text { a] }\end{array}$ & $\begin{array}{c}\text { MACR } \\
0 \\
\text { Julian } \\
\text { days }\end{array}$ & $\begin{array}{l}\text { TOXS } \\
\text { WA } \\
\text { drift } \\
(\%)\end{array}$ \\
\hline $\begin{array}{l}\text { halauxifen- } \\
\text { methyl }\end{array}$ & $\begin{array}{c}\text { Arylex } \\
\text { Technical }\end{array}$ & Cereals, winter & Cereals & $1 /-$ & 0.0782 & $\begin{array}{l}311- \\
341\end{array}$ & 0.5 \\
\hline
\end{tabular}

\begin{tabular}{ll}
\hline Substance input parameters & \\
\hline Molecular mass $(\mathrm{g} / \mathrm{mol})$ & 345 \\
\hline Saturated vapour pressure $(\mathrm{Pa})\left(20^{\circ} \mathrm{C}\right)$ & $5.9 \mathrm{E}-9$ \\
\hline Solubility in water $(\mathrm{mg} / \mathrm{L})$ & 1.7 \\
\hline Arithmetic mean $\mathrm{Kom}(\mathrm{mL} / \mathrm{g})$ & 577 \\
\hline Arithmetic mean $1 / \mathrm{n}$ & 0.87 \\
\hline Factor plant uptake & 0.0 (conservative default) \\
\hline Geometric mean DT 50 water $\left(\mathrm{DT}_{50}\right.$ system) $(\mathrm{d})$ & 1.8 \\
\hline Geometric mean field/lab DT 50 soil $(\mathrm{d})$ & 20 \\
\hline $\mathrm{DT}_{50}$ sediment $(\mathrm{d})$ & 1000 (default) \\
\hline $\mathrm{DT}_{50}$ crop $(\mathrm{d})$ & 10 (default)
\end{tabular}




\begin{tabular}{|c|c|c|c|c|c|c|c|}
\hline Substance & Product & D3 Use & $\begin{array}{l}\text { Droplet } \\
\text { Crop }\end{array}$ & $\begin{array}{l}\text { Freq./ } \\
\text { interval }\end{array}$ & $\begin{array}{c}\text { Dose } \\
\text { rate } \\
\text { [kg/ha] }\end{array}$ & $\begin{array}{c}\text { MACR } \\
\text { O } \\
\text { Julian } \\
\text { days }\end{array}$ & $\begin{array}{c}\text { TOXS } \\
\text { WA } \\
\text { drift } \\
(\%)\end{array}$ \\
\hline \multirow[t]{3}{*}{$\begin{array}{l}\text { thiencarbazon- } \\
\text { methyl }\end{array}$} & Capreno & Maize & Maize & $1 /-$ & 0.1 & $\begin{array}{c}111- \\
141\end{array}$ & 0.5 \\
\hline & Conviso One & Sugar beet & $\begin{array}{l}\text { Sugar } \\
\text { beets }\end{array}$ & $2 / 10$ & 0.015 & $\begin{array}{c}101- \\
150\end{array}$ & \\
\hline & & $\begin{array}{l}\text { Cereals, } \\
\text { winter }\end{array}$ & Cereals & $1 /-$ & 0.0075 & $\begin{array}{c}311- \\
341\end{array}$ & \\
\hline \multicolumn{8}{|c|}{ Substance input parameters } \\
\hline \multicolumn{3}{|c|}{ Molecular mass $(\mathrm{g} / \mathrm{mol})$} & \multicolumn{2}{|l|}{390.4} & & & \\
\hline \multicolumn{3}{|c|}{ Saturated vapour pressure $(\mathrm{Pa})\left(20^{\circ} \mathrm{C}\right)$} & \multicolumn{2}{|l|}{$8.8 \mathrm{E}-14$} & & & \\
\hline \multicolumn{3}{|c|}{ Solubility in water (mg/L) } & \multicolumn{2}{|l|}{436} & & & \\
\hline \multicolumn{3}{|c|}{ Arithmetic mean Kom $(\mathrm{mL} / \mathrm{g})$} & \multicolumn{2}{|l|}{58} & & & \\
\hline \multicolumn{3}{|c|}{ Arithmetic mean $1 / \mathrm{n}$} & \multicolumn{2}{|l|}{0.91} & & & \\
\hline \multicolumn{3}{|c|}{ Factor plant uptake } & \multicolumn{2}{|l|}{0.5} & & & \\
\hline \multicolumn{3}{|c|}{ Geometric mean $\mathrm{DT}_{50}$ water (DT 50 system) (d) } & \multicolumn{2}{|l|}{26.1} & & & \\
\hline \multicolumn{3}{|c|}{ Geometric mean field/lab DT 50 soil (d) } & \multicolumn{2}{|l|}{11.6} & & & \\
\hline \multicolumn{3}{|c|}{$\mathrm{DT}_{50}$ sediment $(\mathrm{d})$} & \multicolumn{2}{|c|}{1000 (default) } & & & \\
\hline \multicolumn{3}{|l|}{ DT 50 crop (d) } & \multicolumn{2}{|c|}{10 (default) } & & & \\
\hline Substance & Product & D3 Use & $\begin{array}{l}\text { Droplet } \\
\text { Crop }\end{array}$ & $\begin{array}{l}\text { Freq./ } \\
\text { interv } \\
\text { al }\end{array}$ & $\begin{array}{l}\text { Dose } \\
\text { rate } \\
{[\mathrm{kg} / \mathrm{h}} \\
\text { a] }\end{array}$ & $\begin{array}{c}\text { MACR } \\
0 \\
\text { Julian } \\
\text { days }\end{array}$ & $\begin{array}{c}\text { TOXS } \\
\text { WA } \\
\text { drift } \\
(\%)\end{array}$ \\
\hline Penflufen & Emesto Silver & $\begin{array}{c}\text { Potatoes } \rightarrow \\
\text { incorporation } \\
10 \mathrm{~cm}\end{array}$ & Potatoes & $1 /-$ & 0.1 & $\begin{array}{c}116- \\
146\end{array}$ & - \\
\hline Substance inpu & rameters & & & & & & \\
\hline Molecular mass & & & 317.41 & & & & \\
\hline Saturated vapou & ssure $(\mathrm{Pa})\left(20^{\circ} \mathrm{C}\right)$ & & $4.1 \mathrm{E}-7$ & & & & \\
\hline Solubility in wat & $g / L)$ & & 12.4 & & & & \\
\hline Arithmetic mean & $(\mathrm{mL} / \mathrm{g})$ & & 279.9 & & & & \\
\hline Arithmetic mean & & & 0.9198 & & & & \\
\hline Factor plant upt & & & 0.0 (cons & ervative de & ult) & & \\
\hline Geometric mean & water (DT 50 syst & n) (d) & 221 & & & & \\
\hline Geometric mean & /lab DT 50 soil $(\mathrm{d})$ & & 113 & & & & \\
\hline DT 50 sediment $(\mathrm{c}$ & & & 1000 (de & ault) & & & \\
\hline $\mathrm{DT}_{50} \operatorname{crop}(\mathrm{d})$ & & & 10 (defa & & & & \\
\hline
\end{tabular}




\begin{tabular}{|c|c|c|c|c|c|c|c|}
\hline Substance & Product & D3 Use & $\begin{array}{c}\text { Droplet } \\
\text { Crop }\end{array}$ & $\begin{array}{c}\text { Freq./ } \\
\text { interv } \\
\text { al }\end{array}$ & $\begin{array}{c}\text { Dose } \\
\text { rate } \\
\text { [kg/h } \\
\text { a] }\end{array}$ & $\begin{array}{c}\text { MACR } \\
0 \\
\text { Julian } \\
\text { days }\end{array}$ & $\begin{array}{l}\text { TOXS } \\
\text { WA } \\
\text { drift } \\
(\%)\end{array}$ \\
\hline Penthiopyrad & DuPont Cielex & Cereals, winter & Cereals & $1 /-$ & 0.24 & $\begin{array}{l}311- \\
341\end{array}$ & 0.5 \\
\hline
\end{tabular}

\begin{tabular}{ll}
\hline Substance input parameters & \\
\hline Molecular mass $(\mathrm{g} / \mathrm{mol})$ & 359.42 \\
\hline Saturated vapour pressure $(\mathrm{Pa})\left(20^{\circ} \mathrm{C}\right)$ & $6.4 \mathrm{E}-6$ \\
\hline Solubility in water $(\mathrm{mg} / \mathrm{L})\left(20^{\circ} \mathrm{C}\right)$ & $7.53 \mathrm{E}-3$ \\
\hline Arithmetic mean $\mathrm{Kom}(\mathrm{mL} / \mathrm{g})$ & 441 \\
\hline Arithmetic mean $1 / \mathrm{n}$ & 0.96 \\
\hline Factor plant uptake & 0.0 (conservative default) \\
\hline Geometric mean $\mathrm{DT}_{50}$ water $\left(\mathrm{DT}_{50}\right.$ system) $(\mathrm{d})$ & 268 \\
\hline Geometric mean field/lab $\mathrm{DT}_{50}$ soil $(\mathrm{d})$ & 116.2 \\
\hline $\mathrm{DT}_{50}$ sediment $(\mathrm{d})$ & 1000 (default) \\
\hline $\mathrm{DT}_{50}$ crop $(\mathrm{d})$ & 10 (default)
\end{tabular}

\begin{tabular}{|c|c|c|c|c|c|c|c|}
\hline Substance & Product & D3 Use & $\begin{array}{l}\text { Droplet } \\
\text { Crop }\end{array}$ & $\begin{array}{c}\text { Freq./ } \\
\text { interv } \\
\text { al }\end{array}$ & $\begin{array}{c}\text { Dose } \\
\text { rate } \\
\text { [kg/h } \\
\text { a] }\end{array}$ & $\begin{array}{c}\text { MACR } \\
0 \\
\text { Julian } \\
\text { days }\end{array}$ & $\begin{array}{c}\text { TOXS } \\
\text { WA } \\
\text { drift } \\
(\%)\end{array}$ \\
\hline $\begin{array}{l}\text { Flupyrsulfuron- } \\
\text { methyl }\end{array}$ & $\begin{array}{l}\text { DuPont Lexus } \\
\text { SX }\end{array}$ & Cereals, winter & Cereals & $1 /-$ & 0.01 & $\begin{array}{c}311- \\
341\end{array}$ & 0.5 \\
\hline \multicolumn{8}{|c|}{ Substance input parameters } \\
\hline \multicolumn{3}{|c|}{ Molecular mass $(\mathrm{g} / \mathrm{mol})$} & \multicolumn{5}{|l|}{487.4} \\
\hline \multicolumn{3}{|c|}{ Saturated vapour pressure $(\mathrm{Pa})\left(20^{\circ} \mathrm{C}\right)$} & \multicolumn{5}{|l|}{$1 \mathrm{E}-9$} \\
\hline \multicolumn{3}{|c|}{ Solubility in water $(\mathrm{mg} / \mathrm{L})$} & \multicolumn{5}{|l|}{0.61} \\
\hline \multicolumn{3}{|c|}{ Arithmetic mean Kom $(\mathrm{mL} / \mathrm{g})$} & \multicolumn{5}{|l|}{17.1} \\
\hline \multicolumn{3}{|c|}{ Arithmetic mean $1 / \mathrm{n}$} & \multicolumn{5}{|l|}{0.9} \\
\hline \multicolumn{3}{|c|}{ Factor plant uptake } & \multicolumn{5}{|l|}{0.5} \\
\hline \multicolumn{3}{|c|}{ Geometric mean $\mathrm{DT}_{50}$ water (DT50 system) (d) } & \multicolumn{5}{|l|}{4.24} \\
\hline \multicolumn{3}{|c|}{ Geometric mean field/lab DT 50 soil (d) } & \multicolumn{5}{|l|}{16.1} \\
\hline \multicolumn{3}{|c|}{$\mathrm{DT}_{50}$ sediment $(\mathrm{d})$} & \multicolumn{5}{|c|}{1000 (default) } \\
\hline \multicolumn{3}{|l|}{$\mathrm{DT}_{50} \operatorname{crop}(\mathrm{d})$} & \multicolumn{5}{|c|}{10 (default) } \\
\hline
\end{tabular}




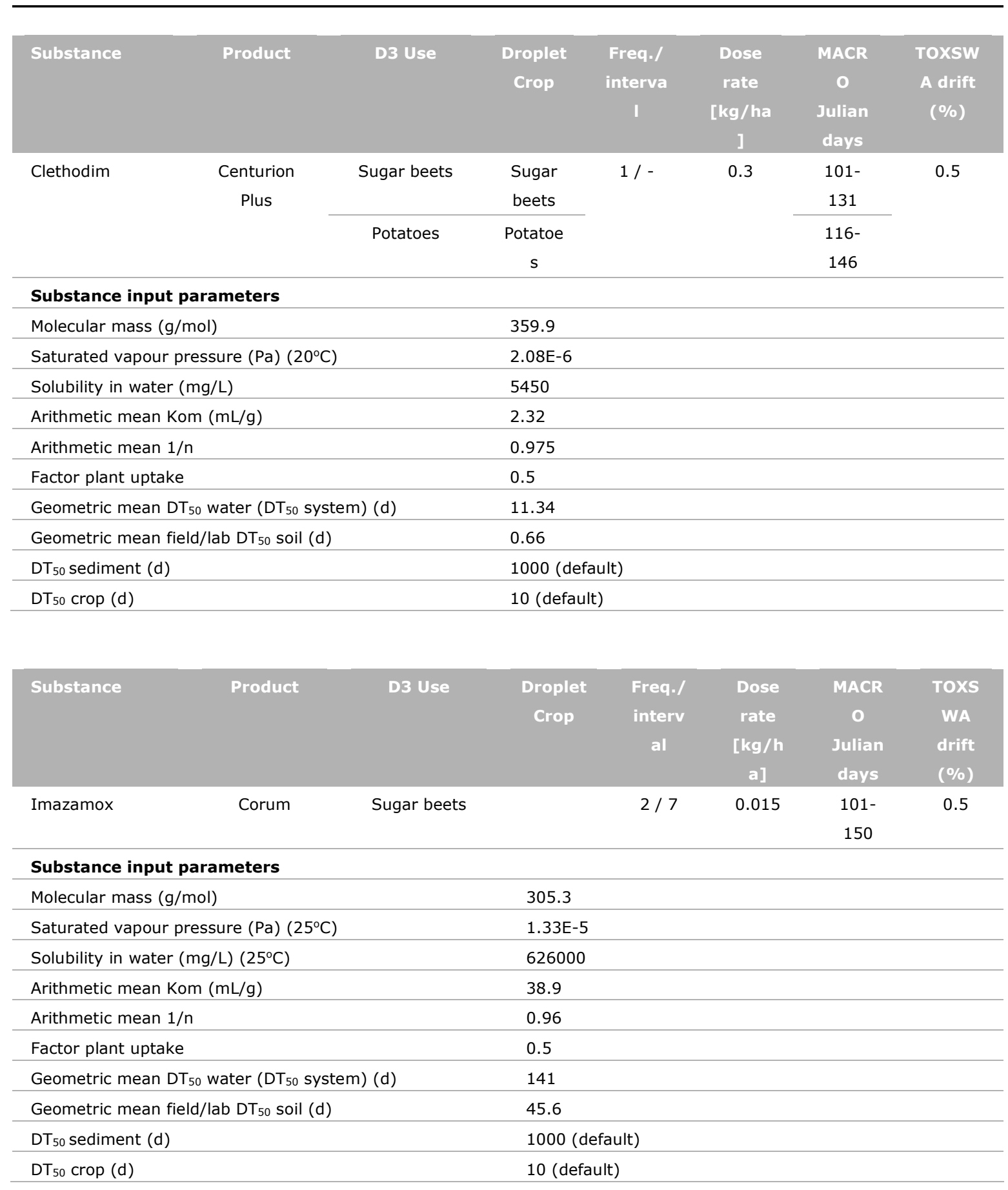




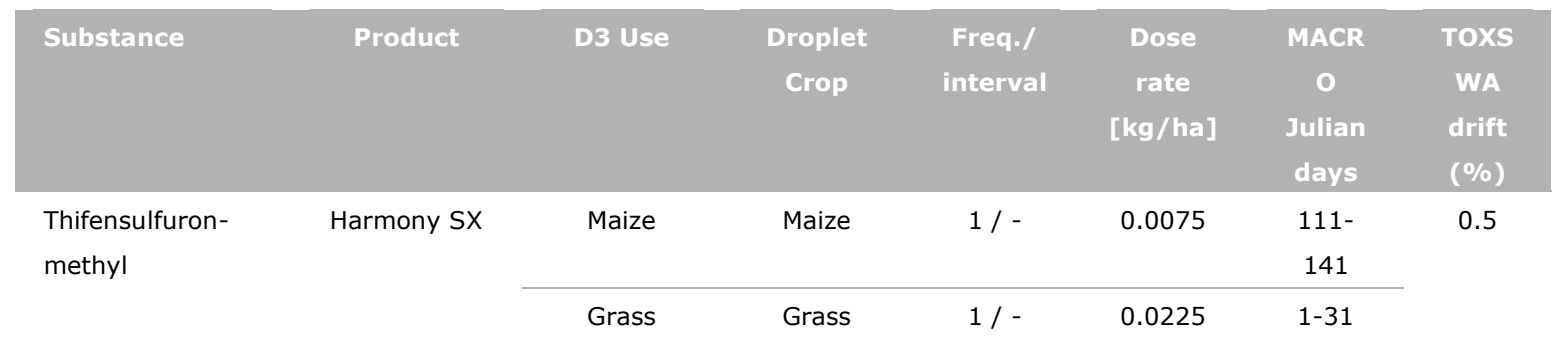

\begin{tabular}{ll}
\hline Substance input parameters & \\
\hline Molecular mass $(\mathrm{g} / \mathrm{mol})$ & 387.4 \\
\hline Saturated vapour pressure $(\mathrm{Pa})\left(20^{\circ} \mathrm{C}\right)$ & $7.5 \mathrm{E}-6$ \\
\hline Solubility in water $(\mathrm{mg} / \mathrm{L})\left(25^{\circ} \mathrm{C}\right)$ & $2.24 \mathrm{E}-3$ \\
\hline Arithmetic mean $\mathrm{Kom}(\mathrm{mL} / \mathrm{g})$ & 16.4 \\
\hline Arithmetic mean $1 / \mathrm{n}$ & 0.9 \\
\hline Factor plant uptake & 0.0 (conservative default) \\
\hline Geometric mean $\mathrm{DT} 50$ water $\left(\mathrm{DT}_{50}\right.$ system) $(\mathrm{d})$ & 23.5 \\
\hline Geometric mean field/lab $\mathrm{DT}_{50}$ soil $(\mathrm{d})$ & 3.4 \\
\hline $\mathrm{DT}_{50}$ sediment $(\mathrm{d})$ & 1000 (default) \\
\hline $\mathrm{DT}_{50}$ crop $(\mathrm{d})$ & 10 (default)
\end{tabular}




\section{Annex 2 Graphical representation of concentration in water layer}

Results from simulations based on the recently

released model versions (i.e. new model suite)

A.s. valifenalate

\section{Potatoes}

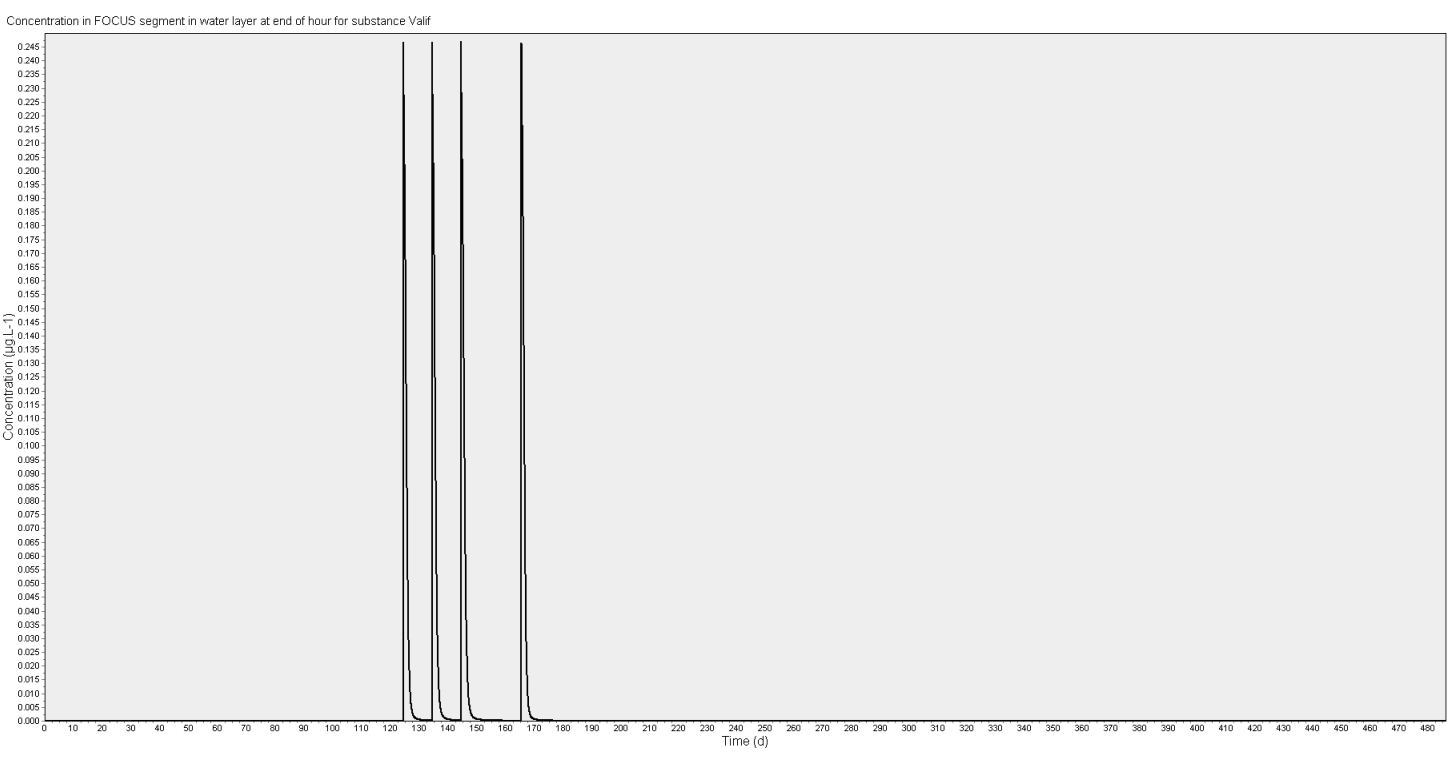

A.s. cyantraniliprole

\section{Potatoes}

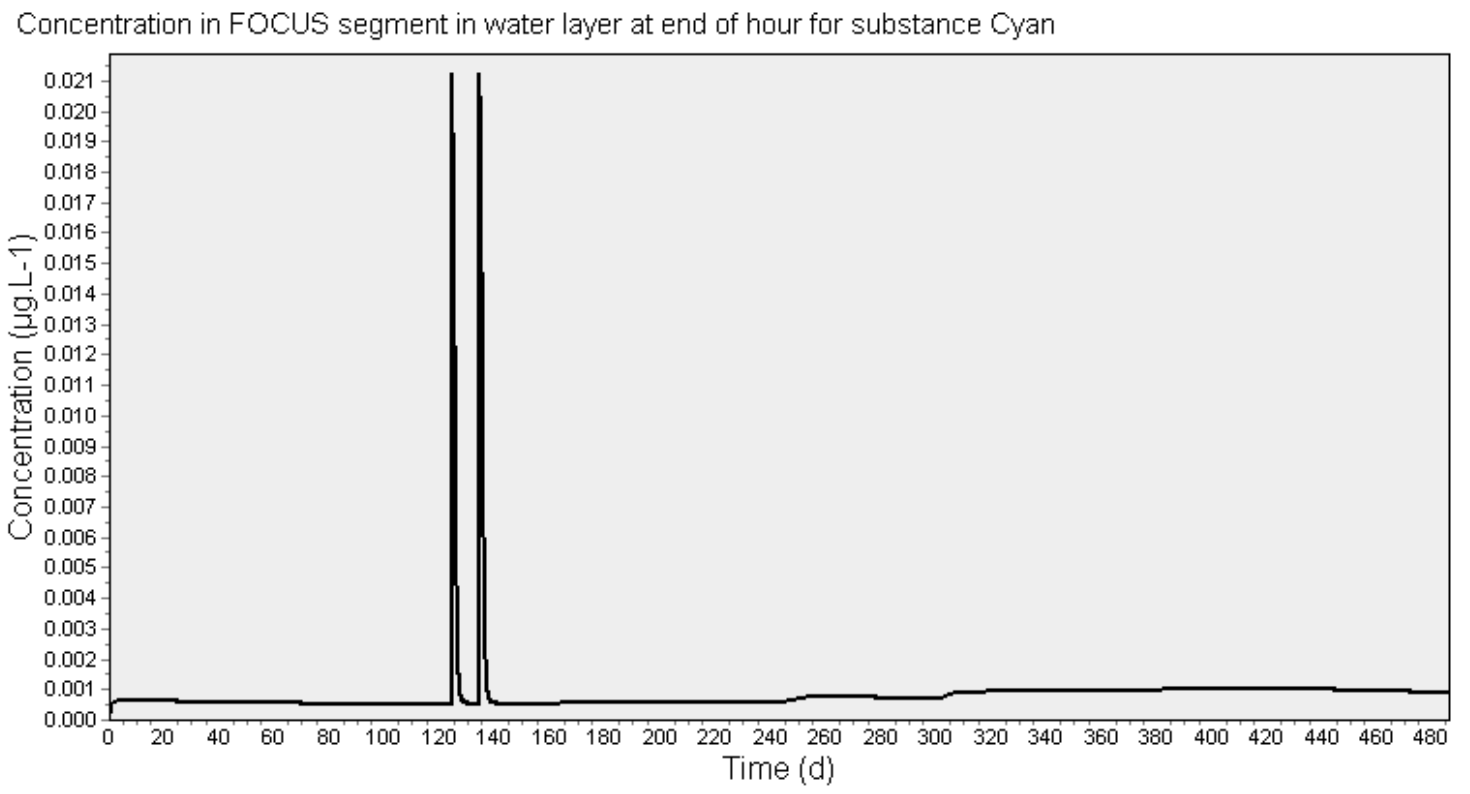




\section{A.s. flupyradifurone}

\section{Pome/stone fruit, early}

\section{Concentration in FOCUS segment in water layer at end of hour for substance Flupyr}

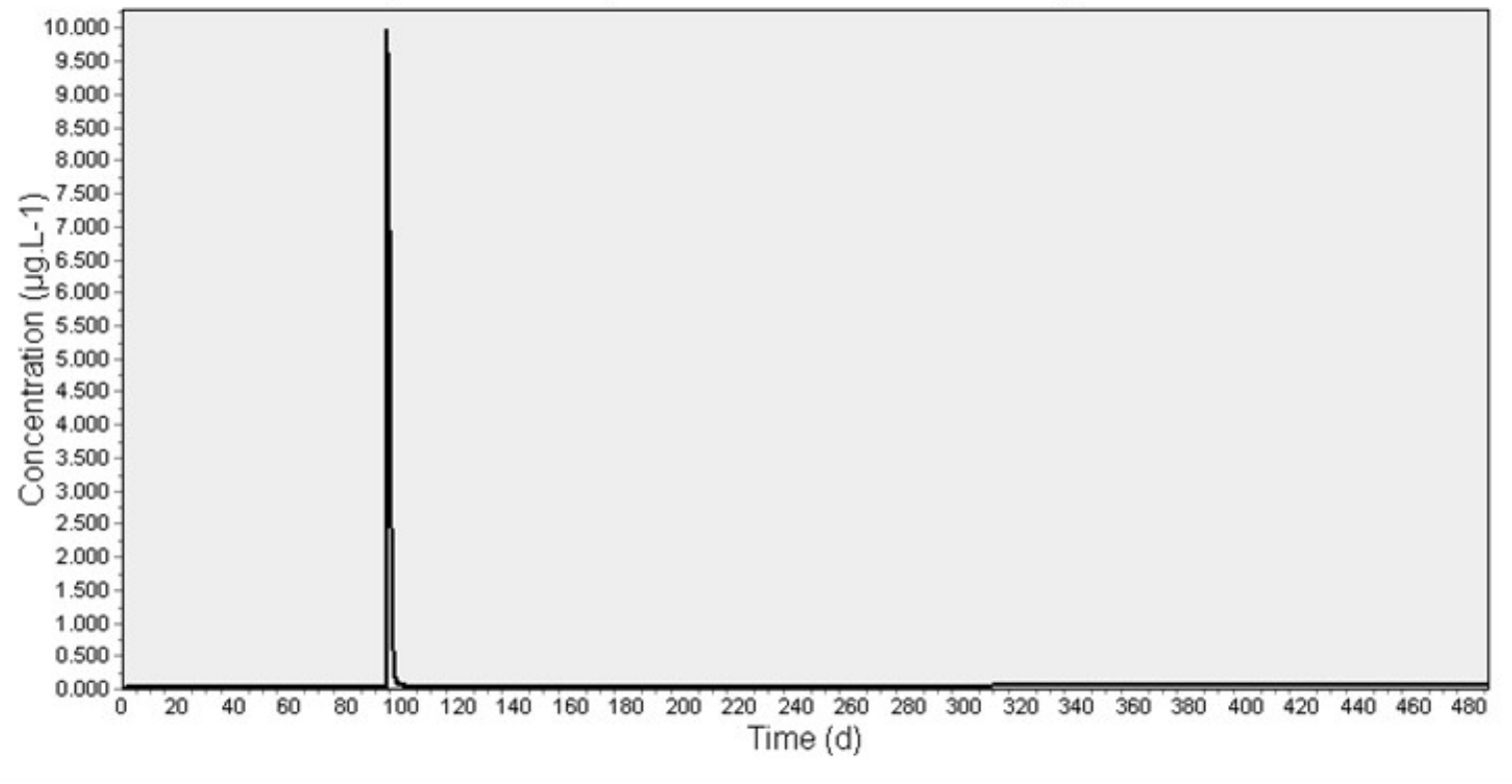

\section{Pome/stone fruit, late}

Concentration in FOCUS segment in water layer at end of hour for substance Flupyr






\section{A.s. benzovindiflupyr}

\section{Cereals, winter}

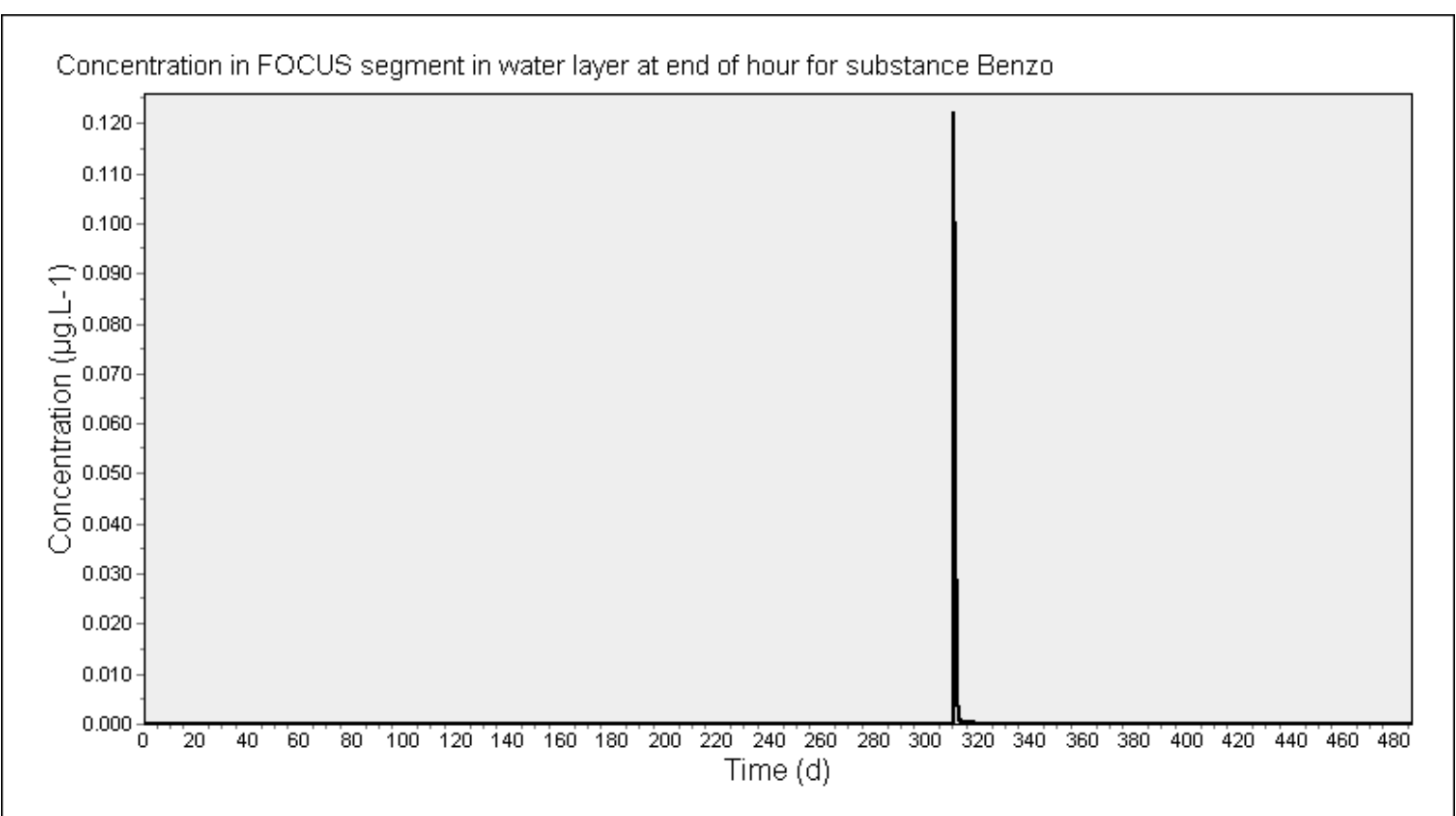

\section{A.s. pyriofenone}

\section{Cereals, winter}

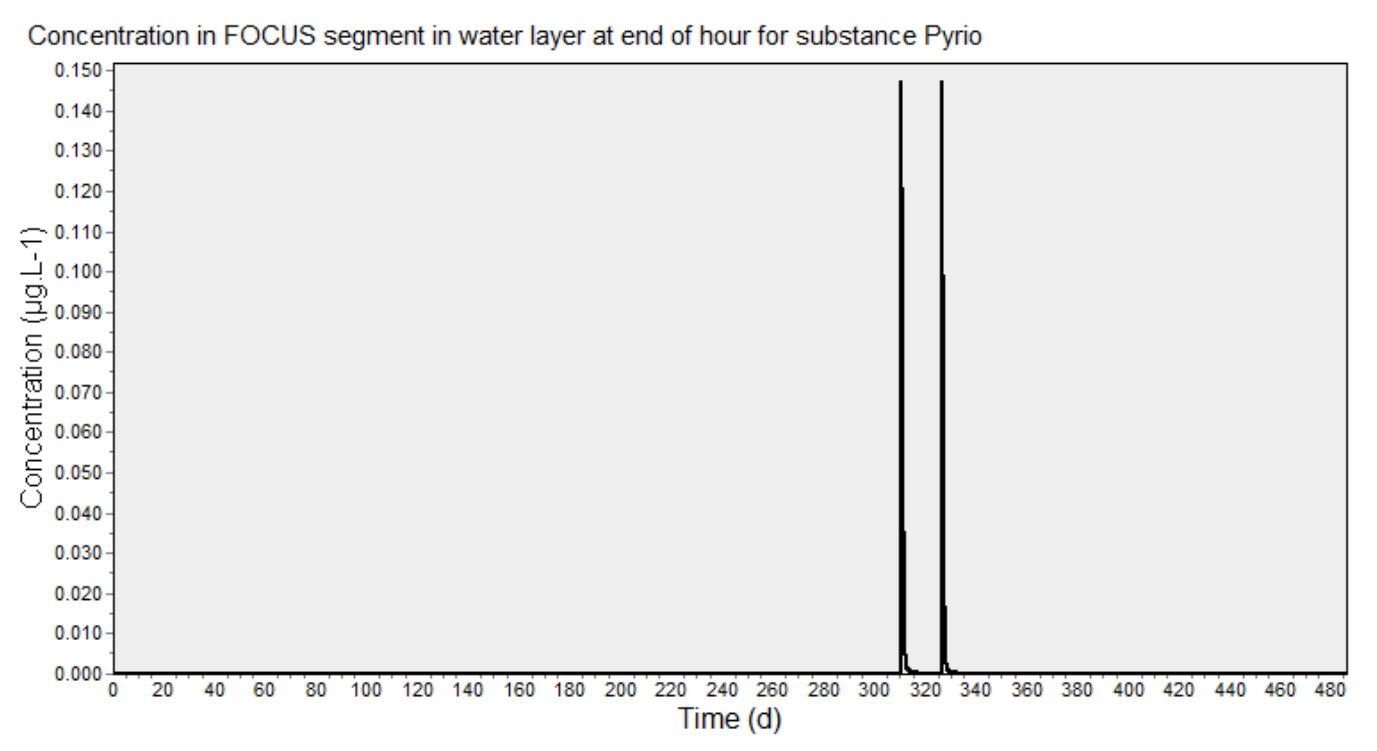




\section{Cereals, spring}

\section{Concentration in FOCUS segment in water layer at end of hour for substance Pyrio}

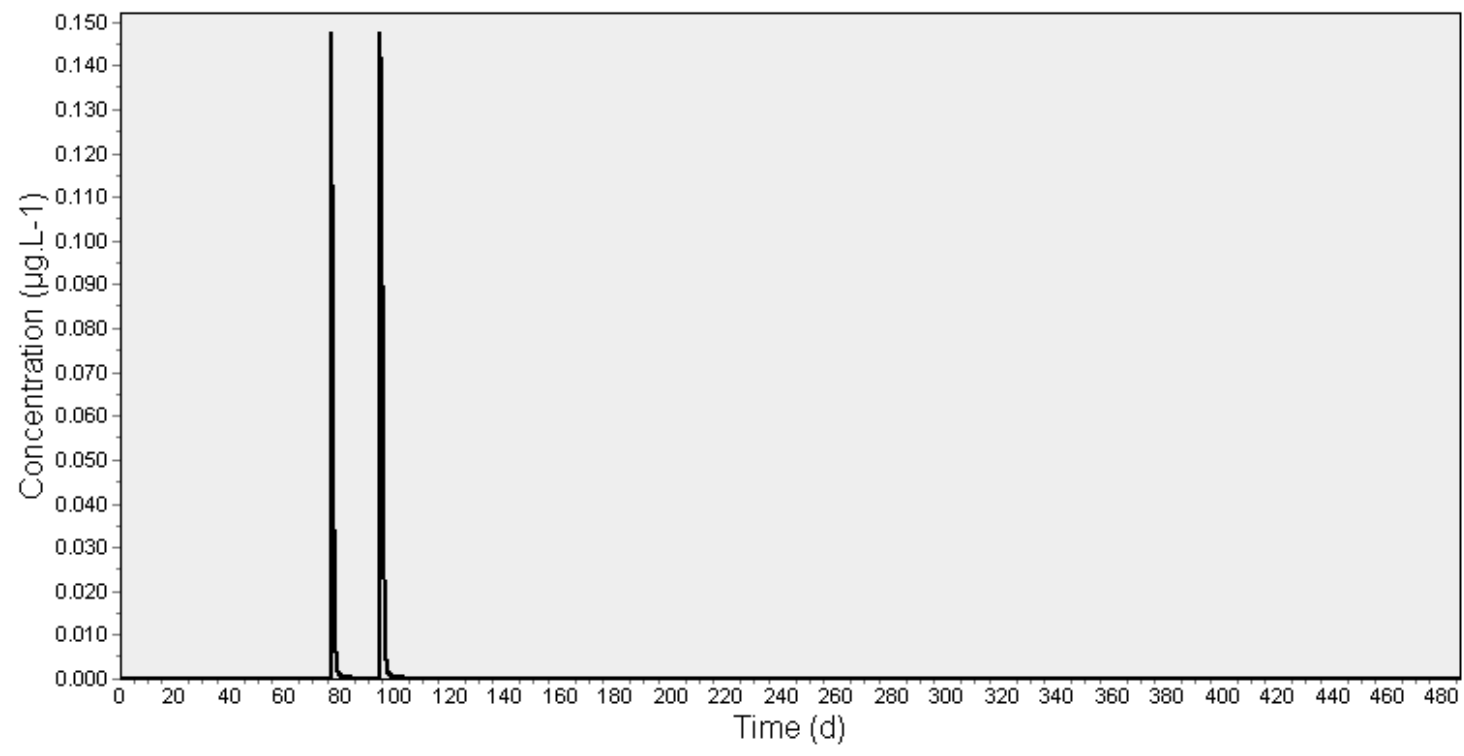

\section{A.s. sedaxane}

\section{Maize}

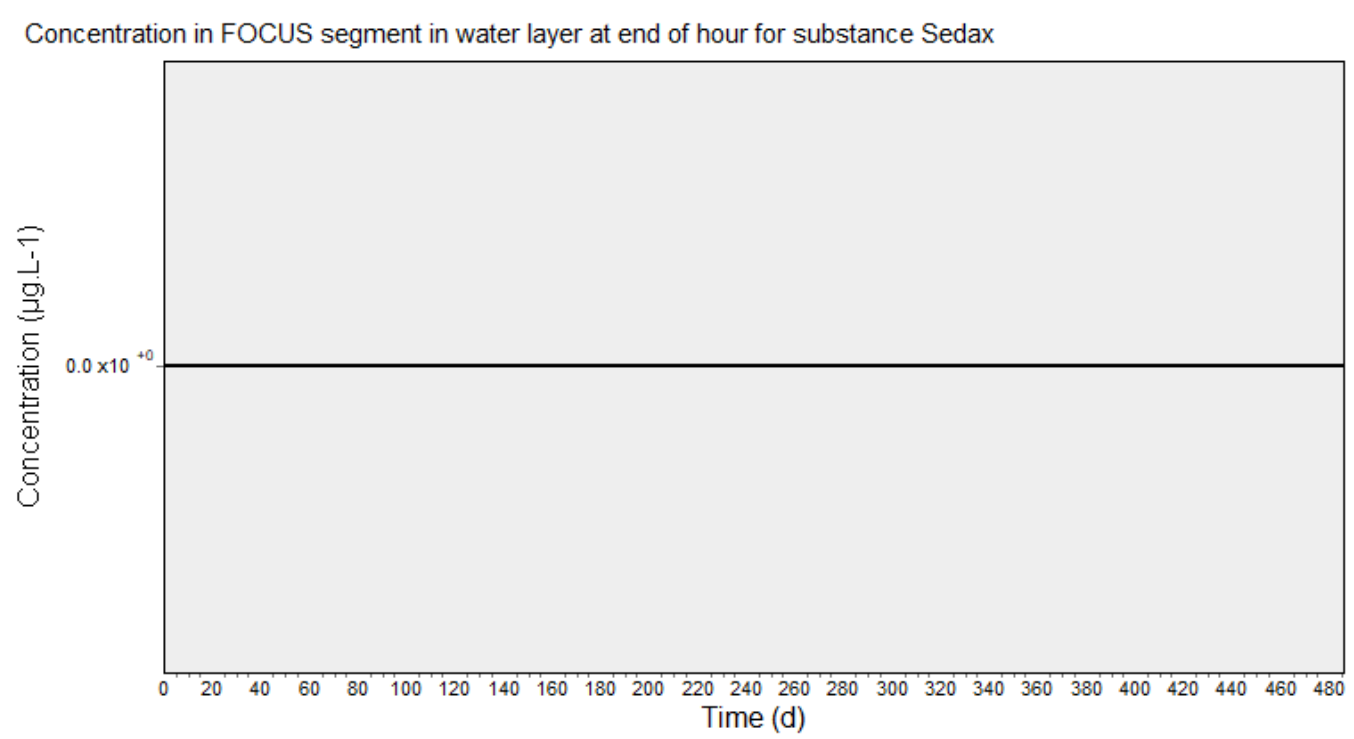




\section{A.s. isoxaben}

\section{Pome/stone fruit, early}

Concentration in FOCUS segment in water layer at end of hour for substance Isox

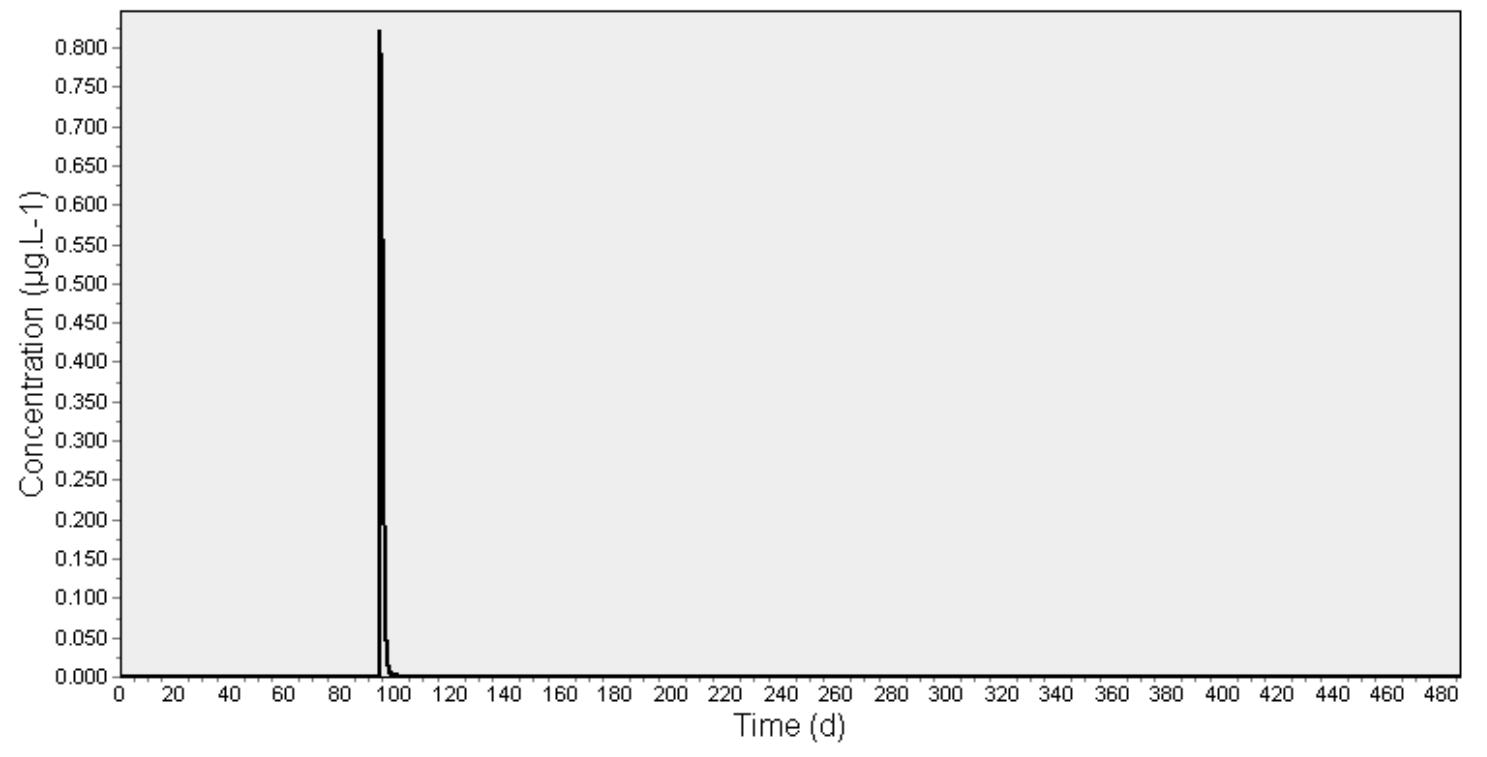

\section{Cereals, winter}

Concentration in FOCUS segment in water layer at end of hour for substance Isox

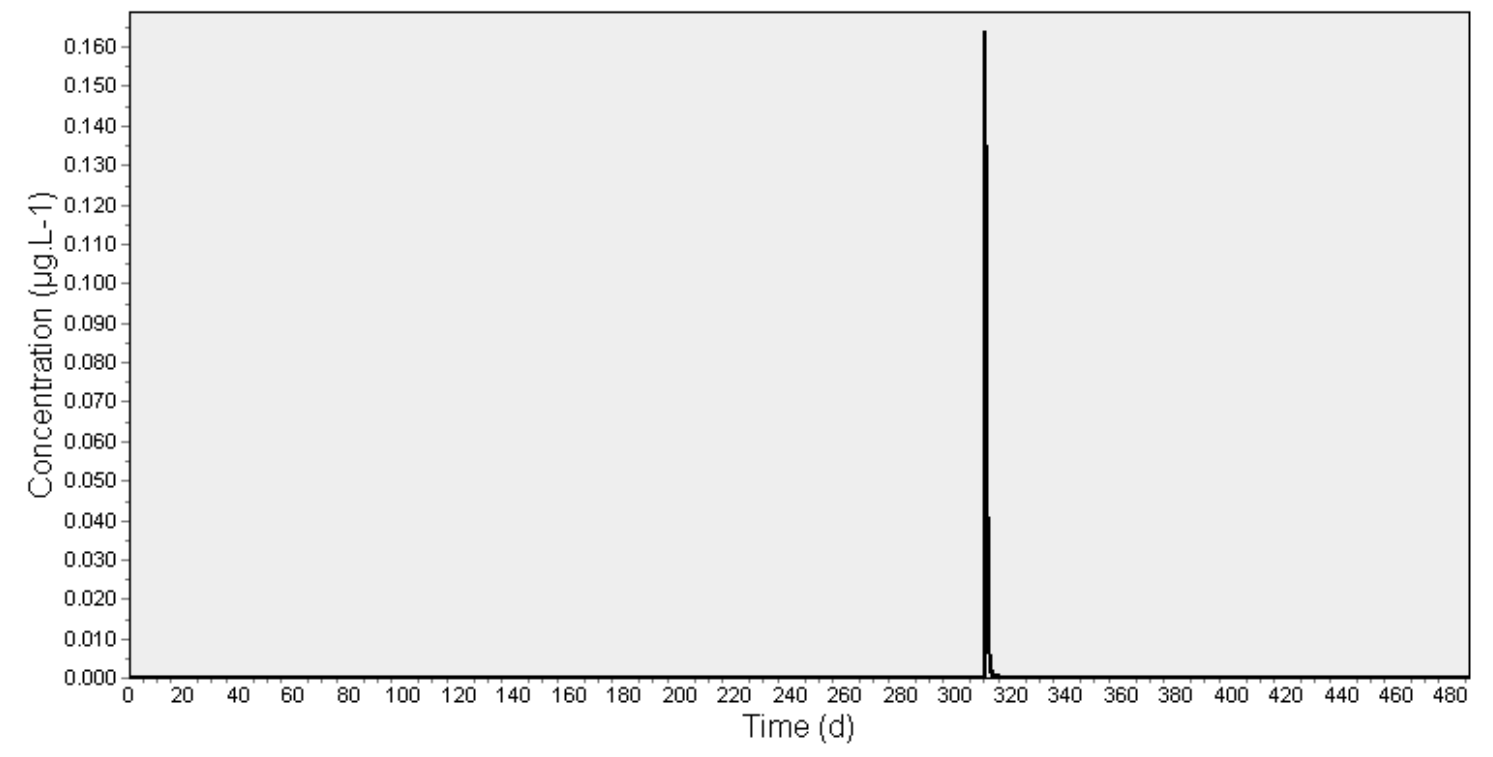




\section{Grass/alfalfa}

Concentration in FOCUS segment in water layer at end of hour for substance Isox

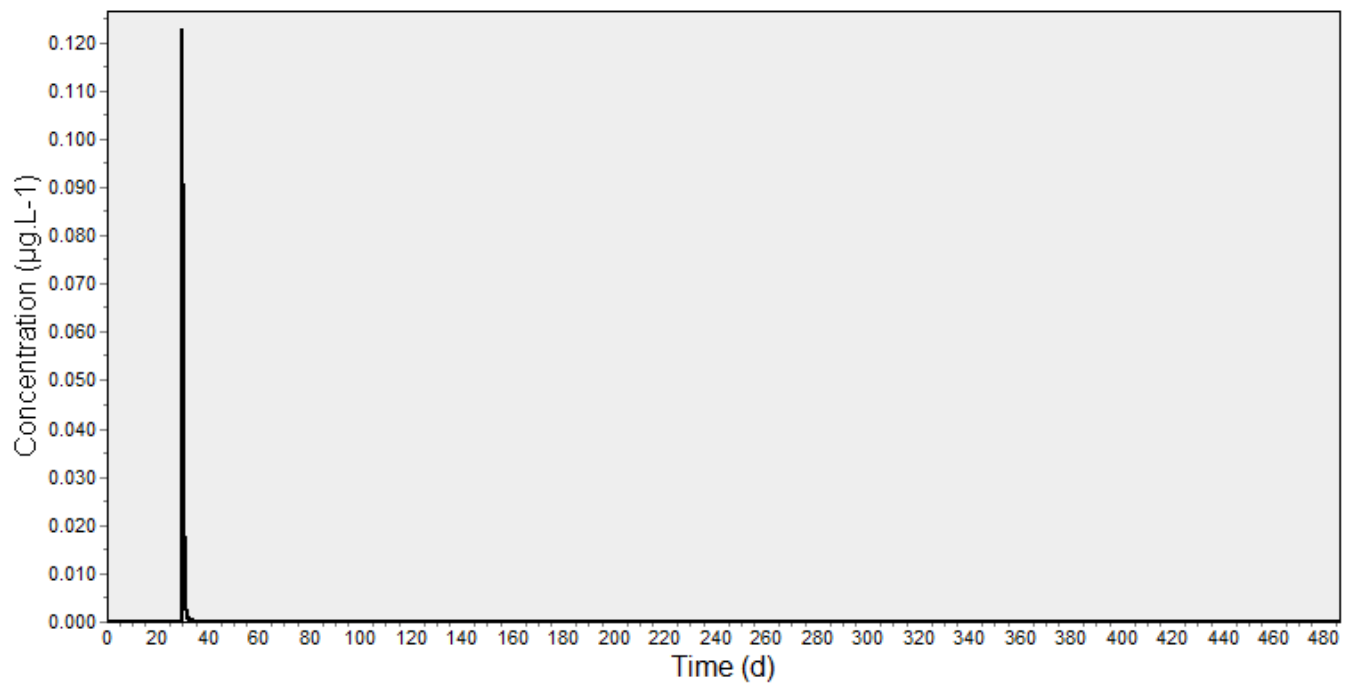

\section{A.s. halauxifen-methyl}

\section{Cereals, winter}

Concentration in FOCUS segment in water layer at end of hour for substance Halau

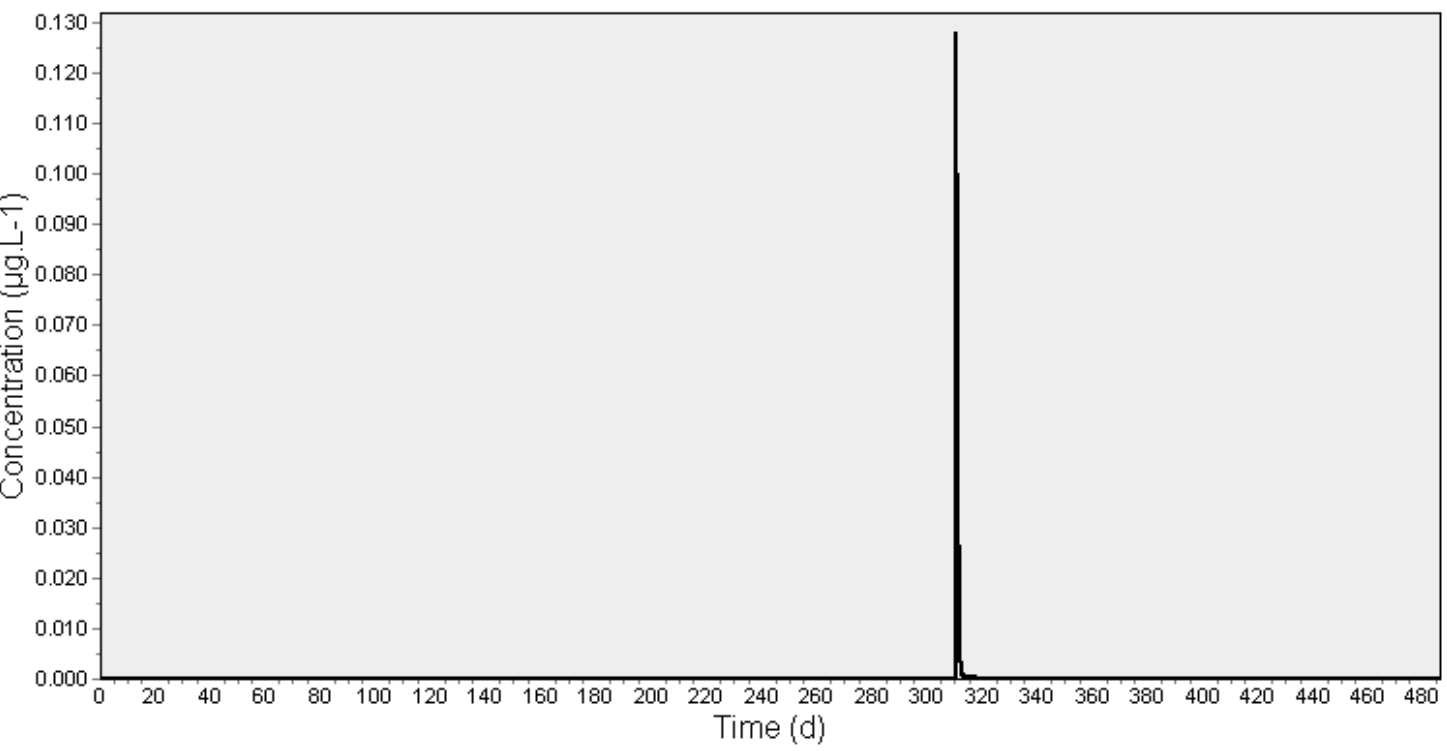




\section{Thiencarbazon-methyl}

\section{Maize}

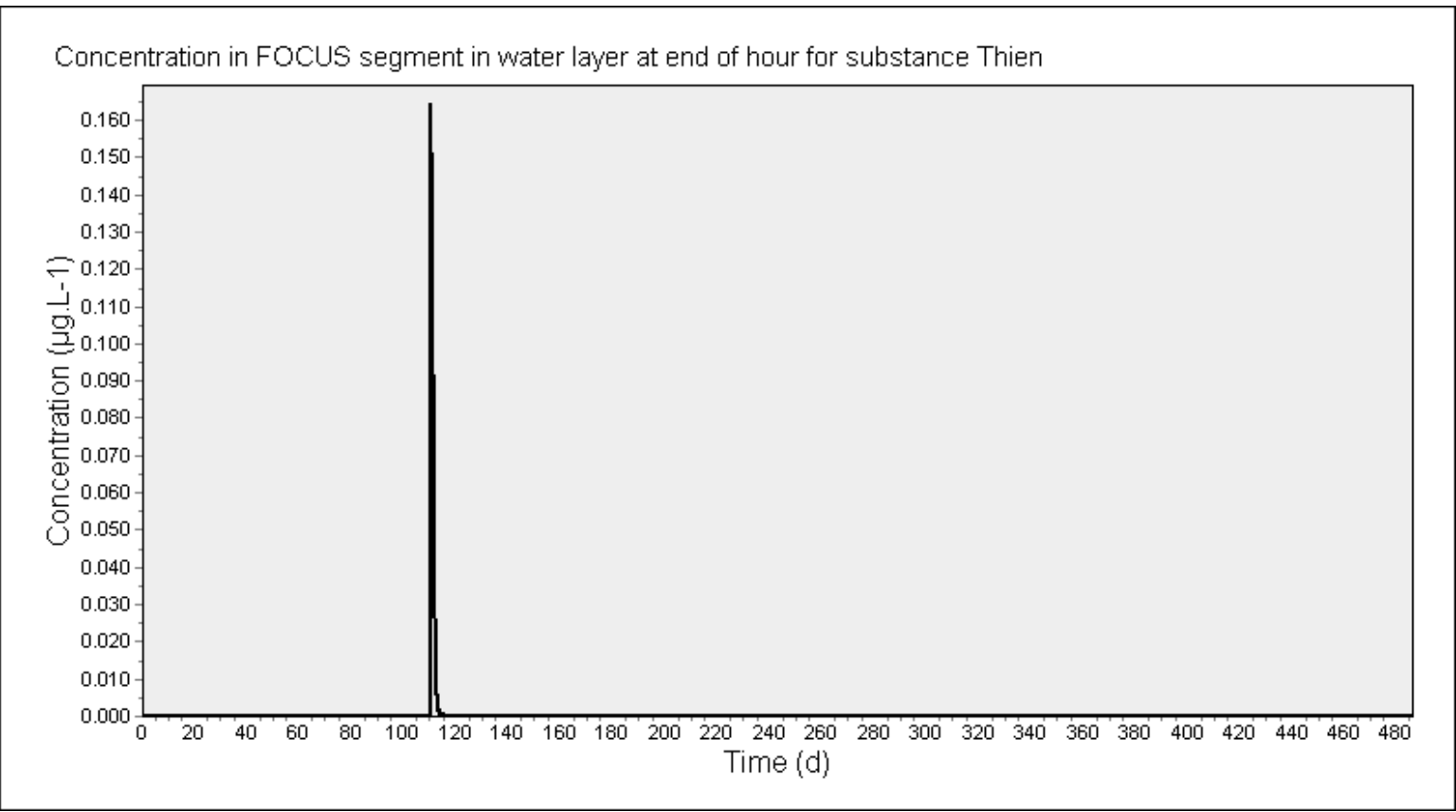

\section{Sugar beet}

Concentration in FOCUS segment in water layer at end of hour for substance Thien

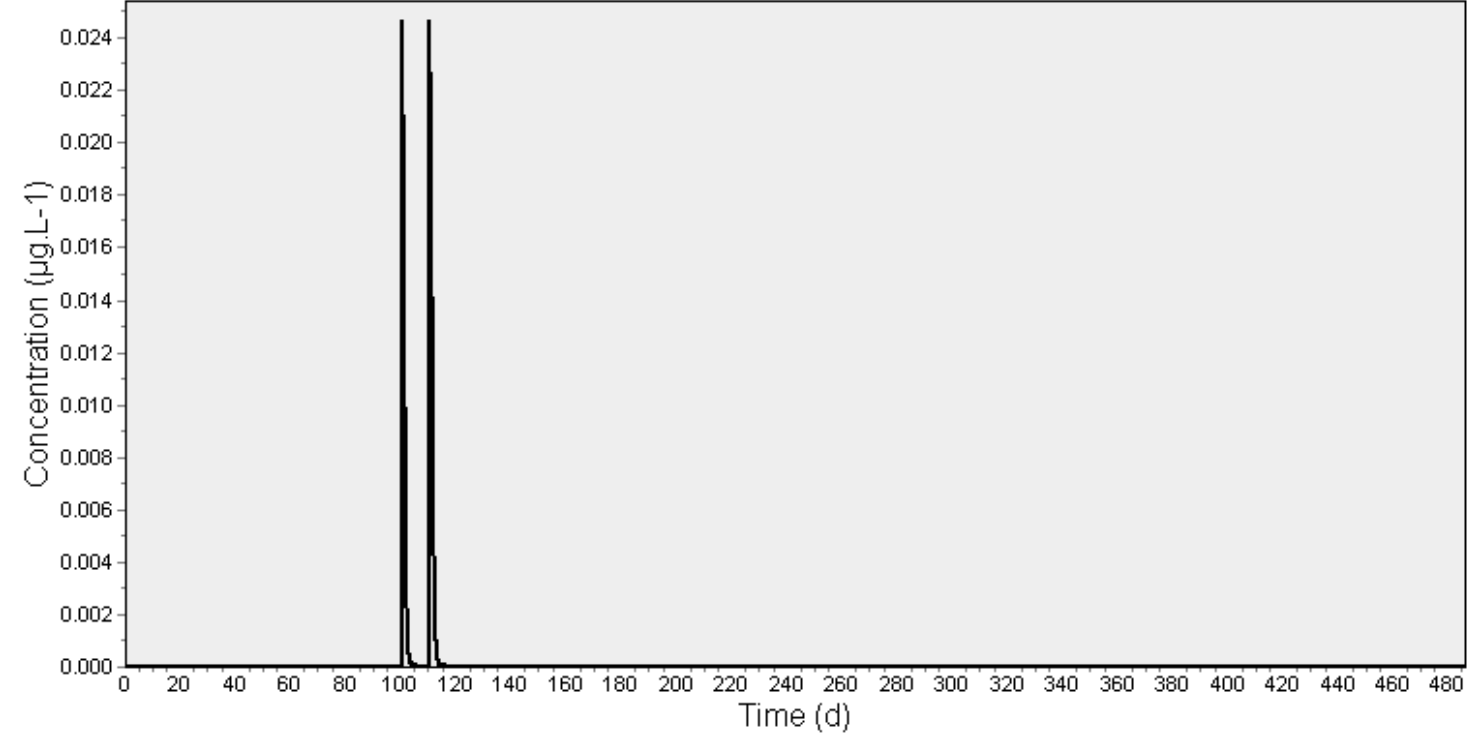




\section{Cereals, winter}

Concentration in FOCUS segment in water layer at end of hour for substance Thien

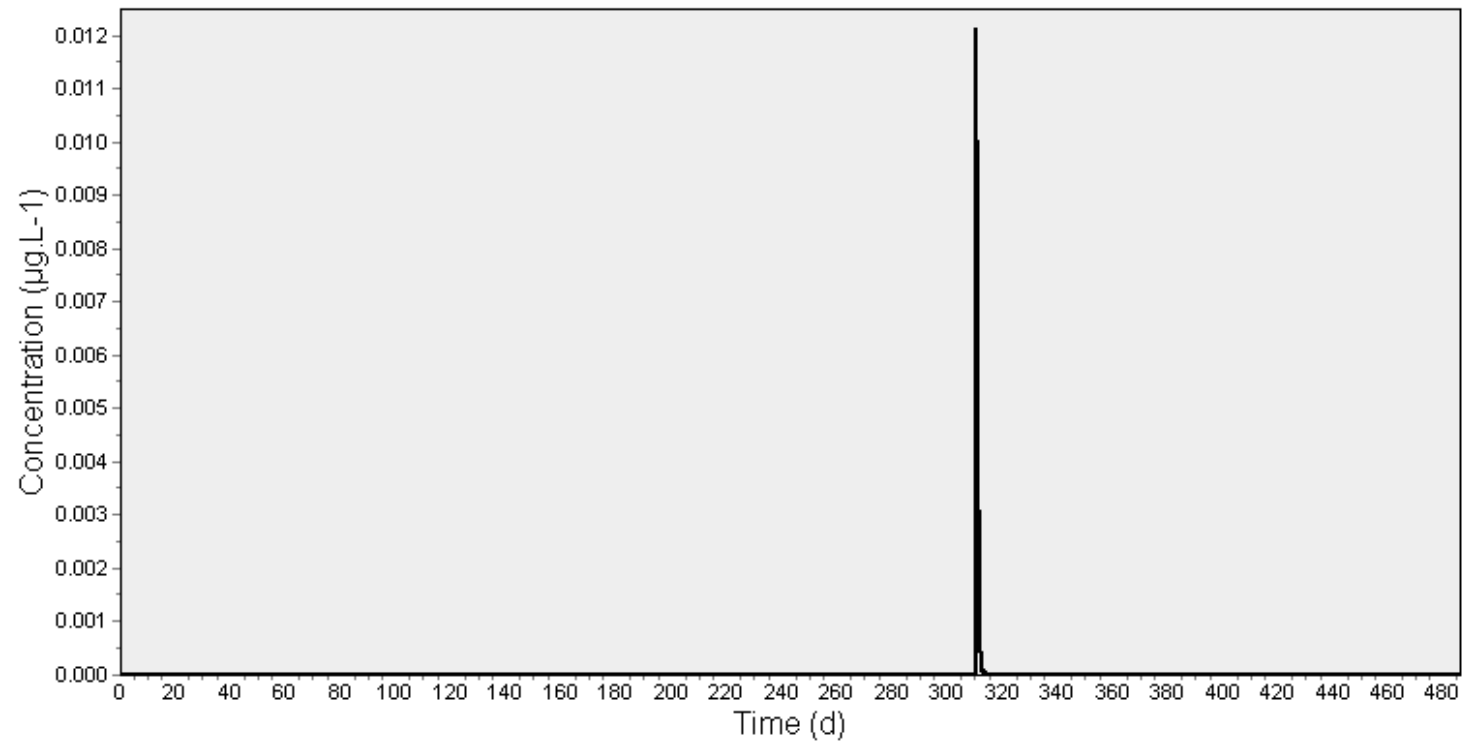

\section{A.s penflufen}

\section{Potatoes}

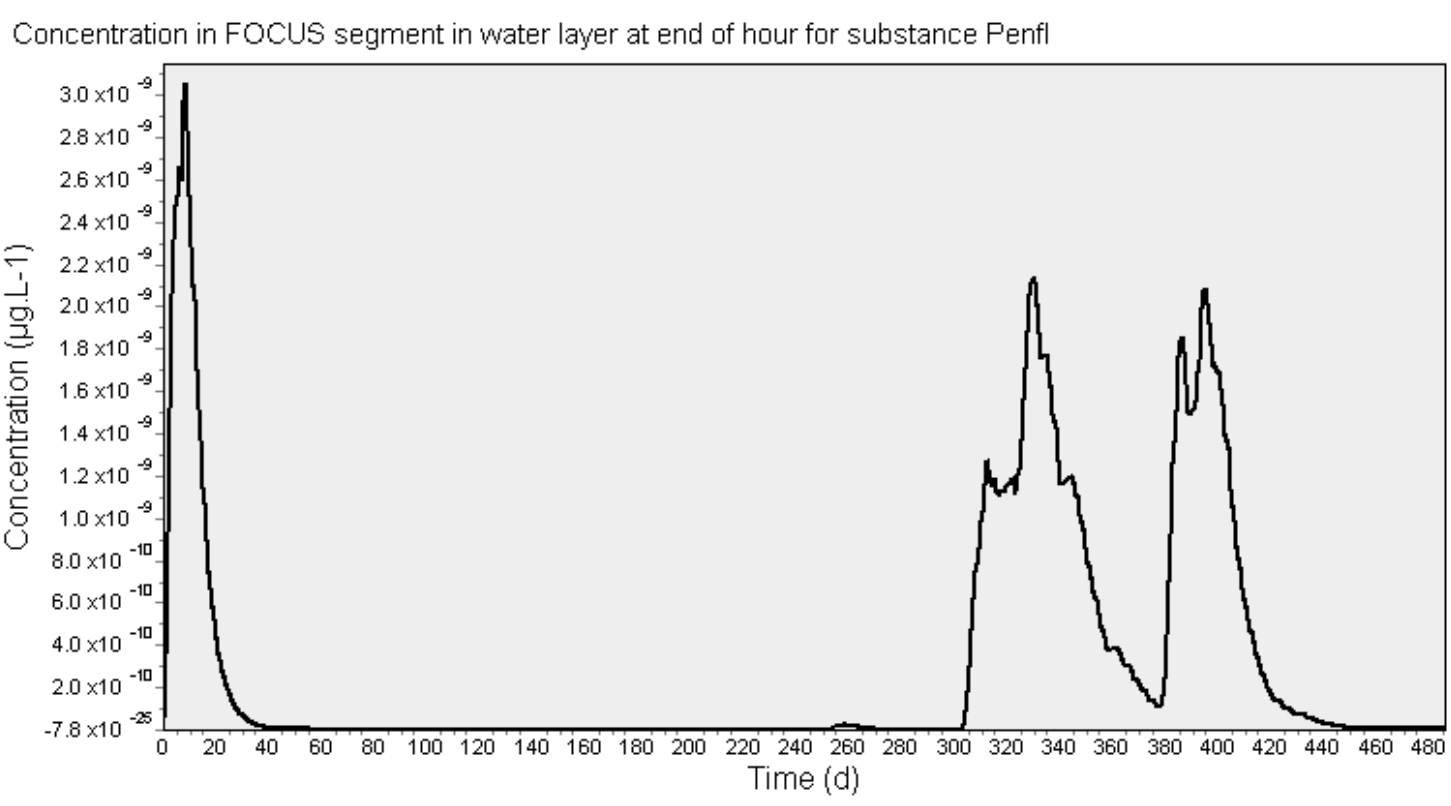




\section{A.s. Penthiopyrad}

\section{Cereals, winter}

Concentration in FOCUS segment in water layer at end of hour for substance Penthio

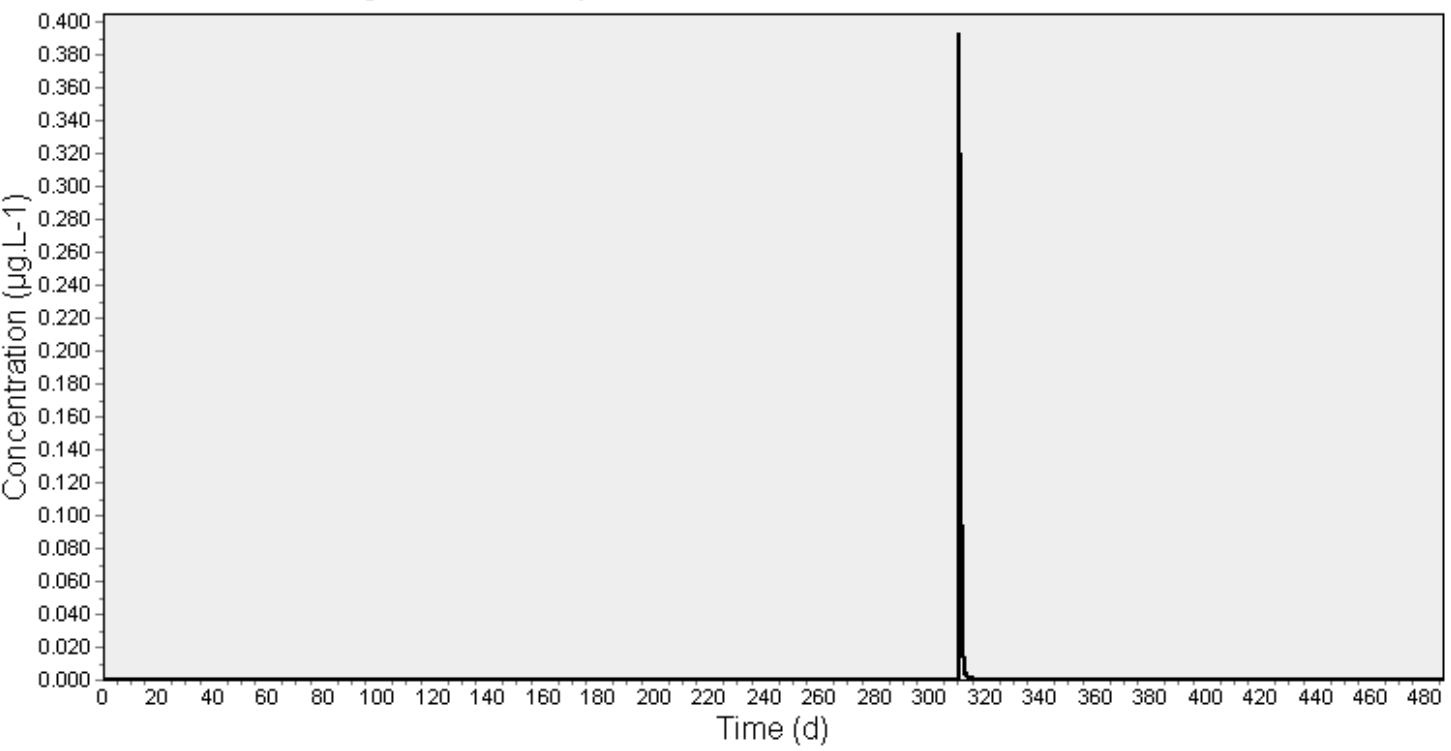

\section{A.s. flupyrsulfuron-methyl}

\section{Cereals, winter}

Concentration in FOCUS segment in water layer at end of hour for substance Flupyr

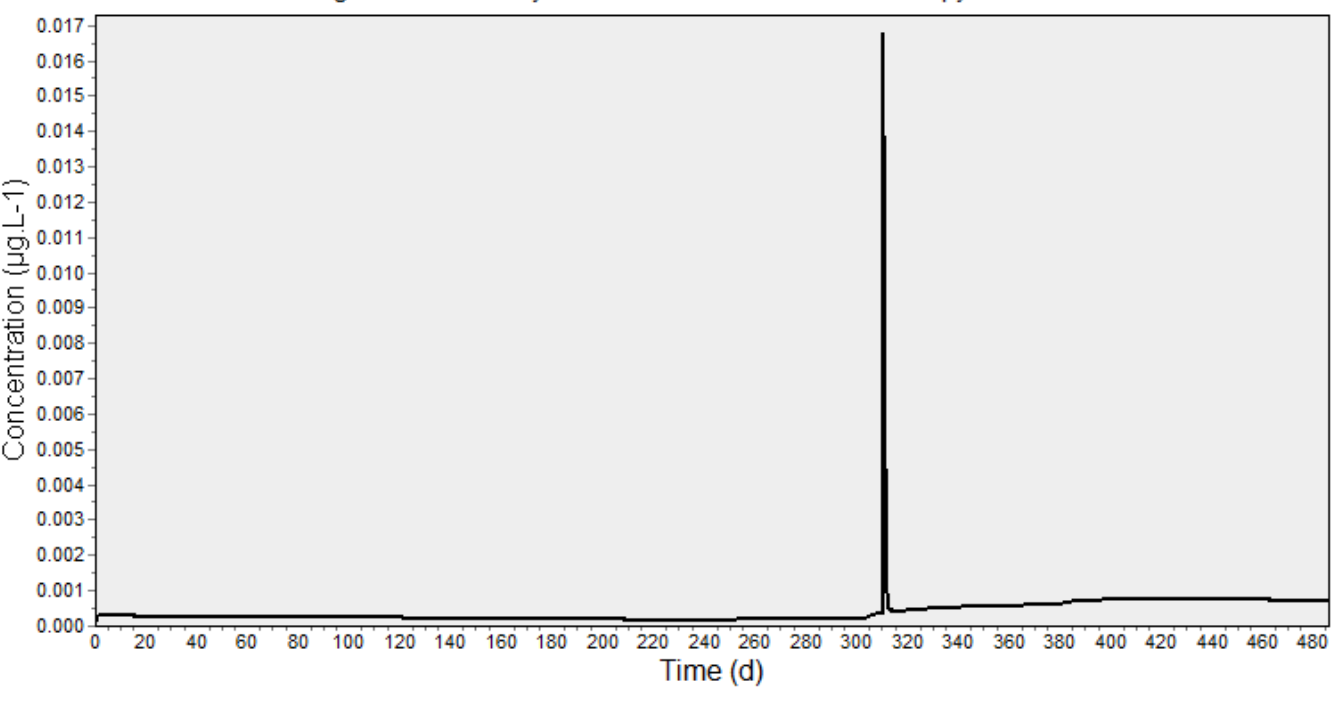




\section{A.s. clethodim}

\section{Sugar beets}

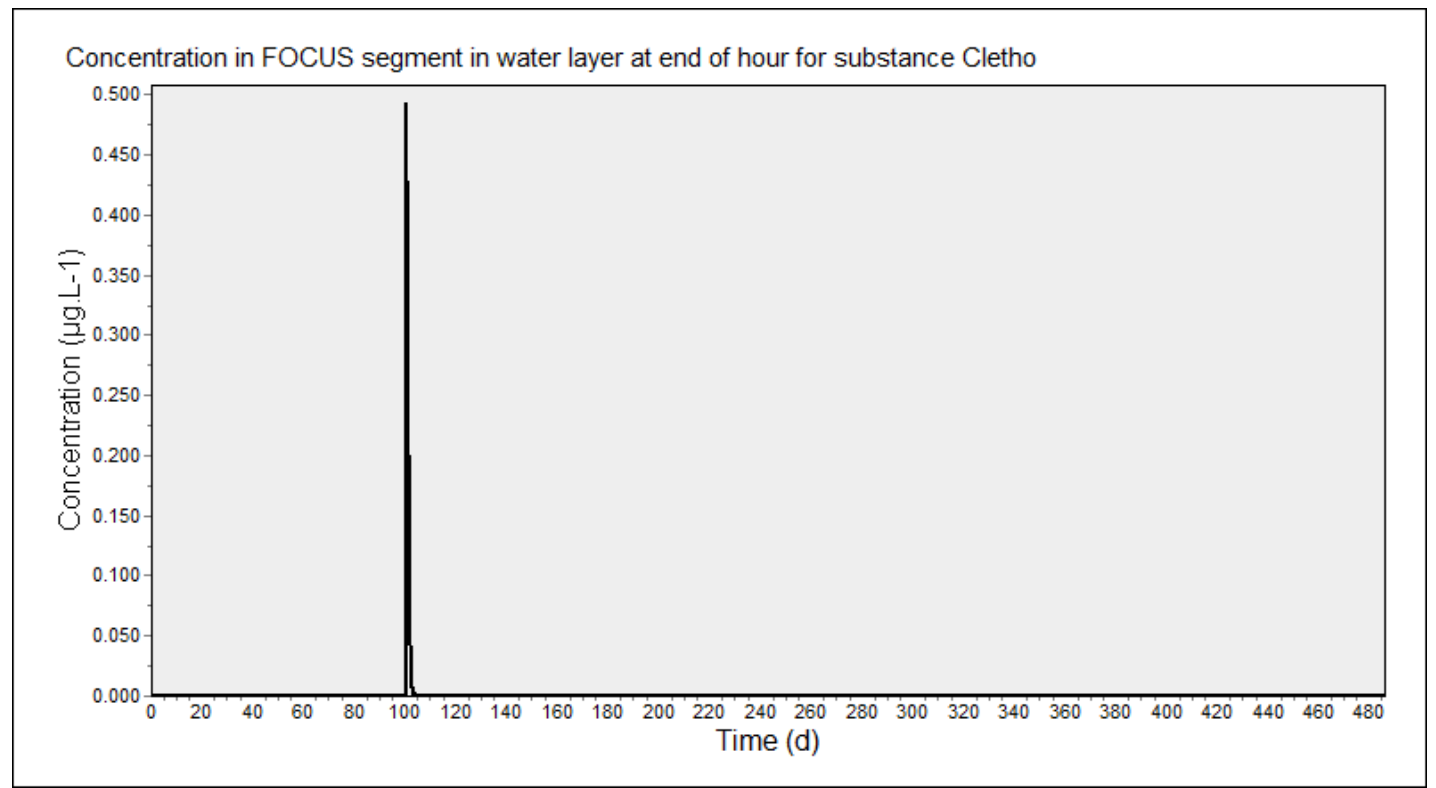

\section{Potatoes}

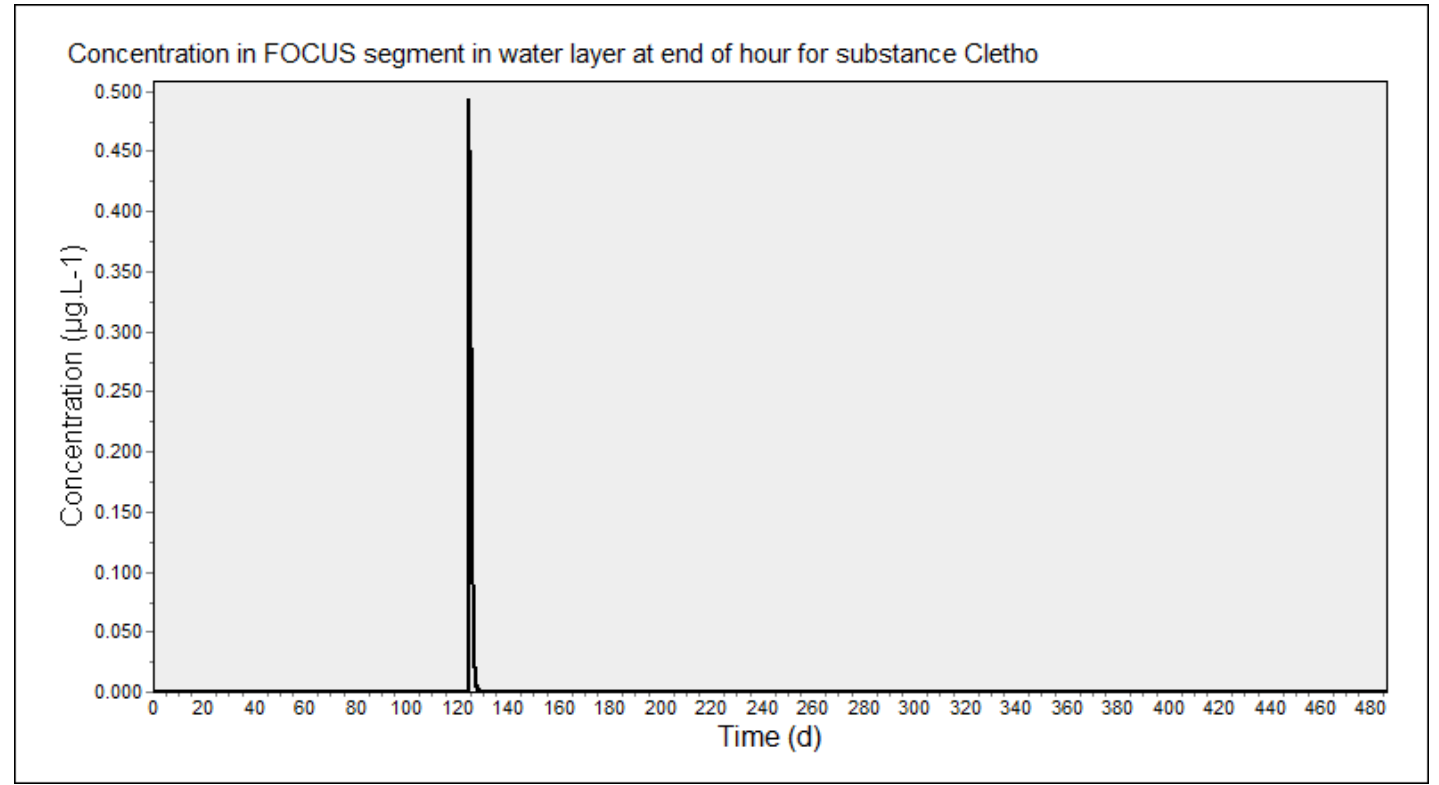




\section{A.s. imazamox}

\section{Sugar beets}

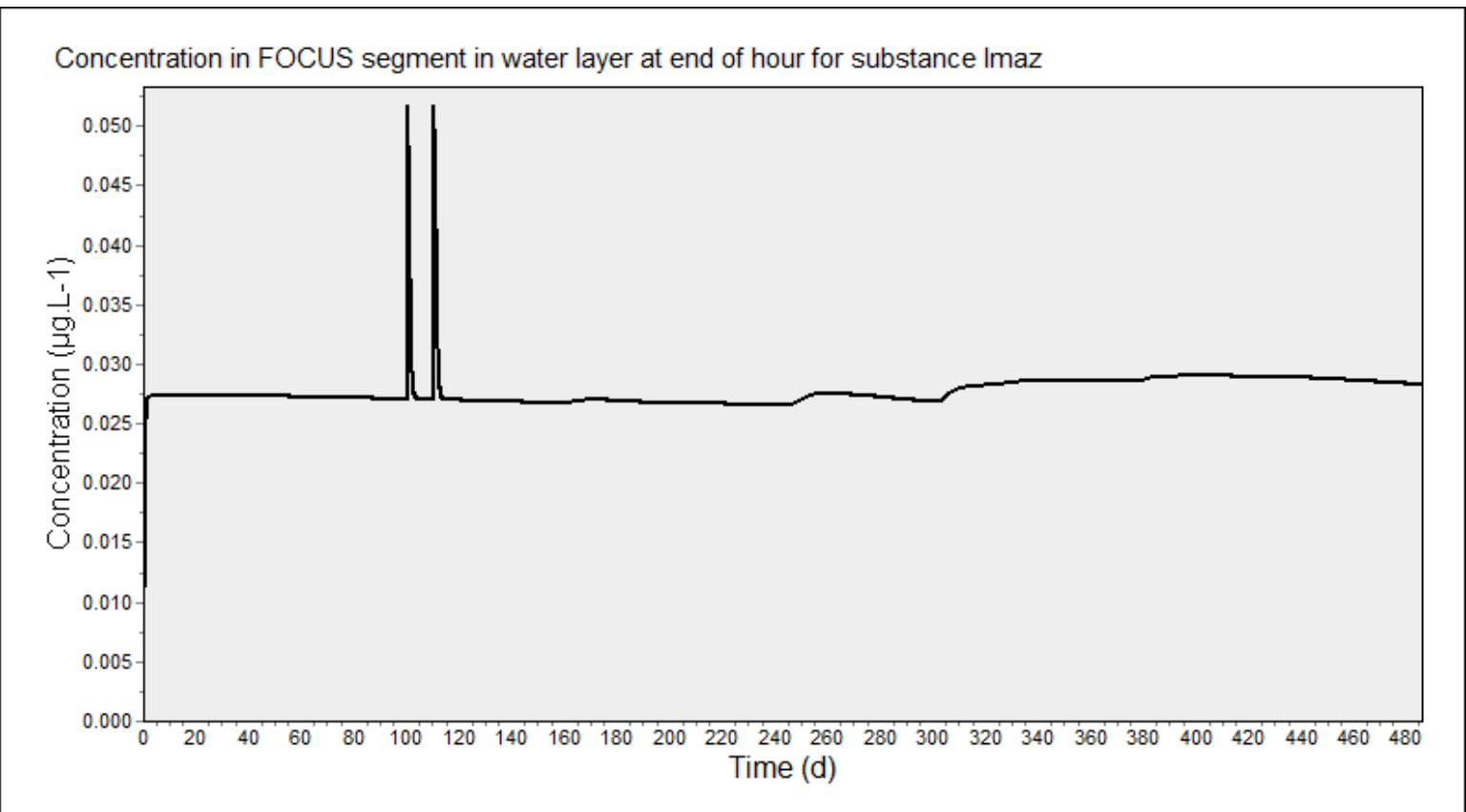

\section{A.s. thifensulfuron-methyl}

\section{Maize}

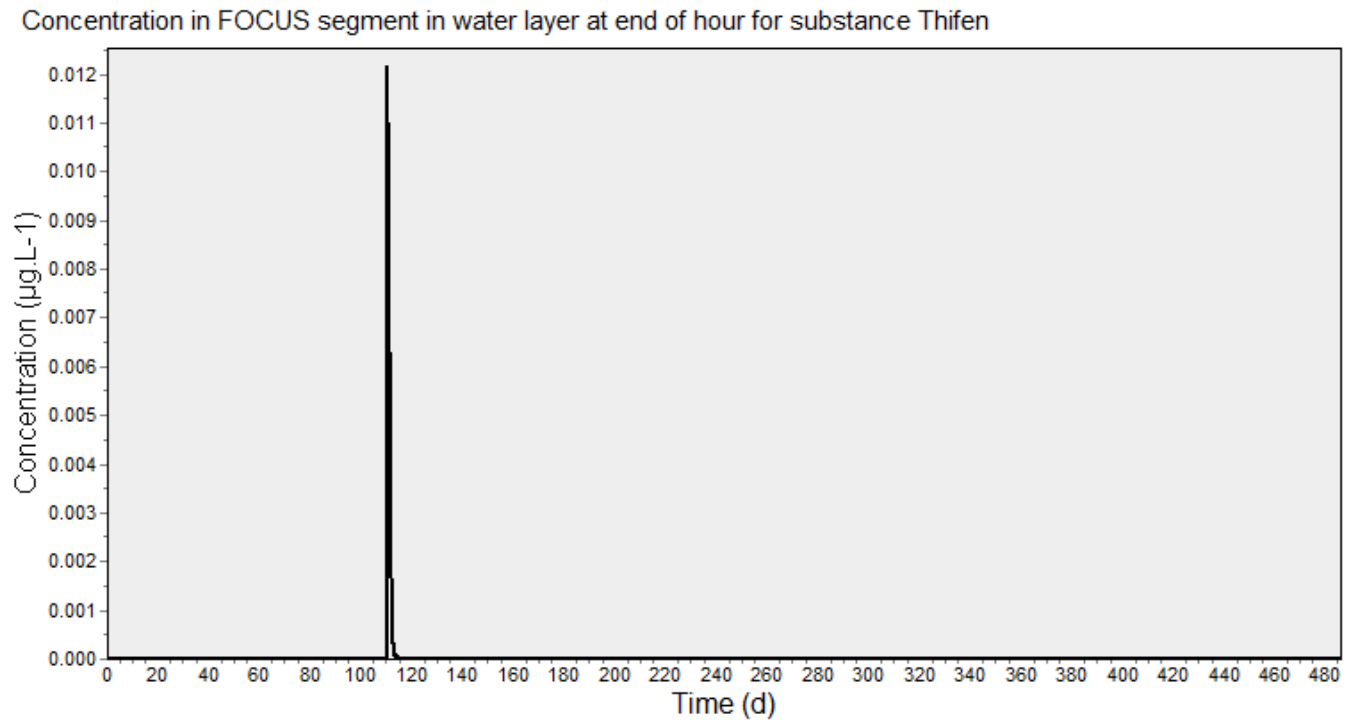




\section{Grass}

Concentration in FOCUS segment in water layer at end of hour for substance Thifen

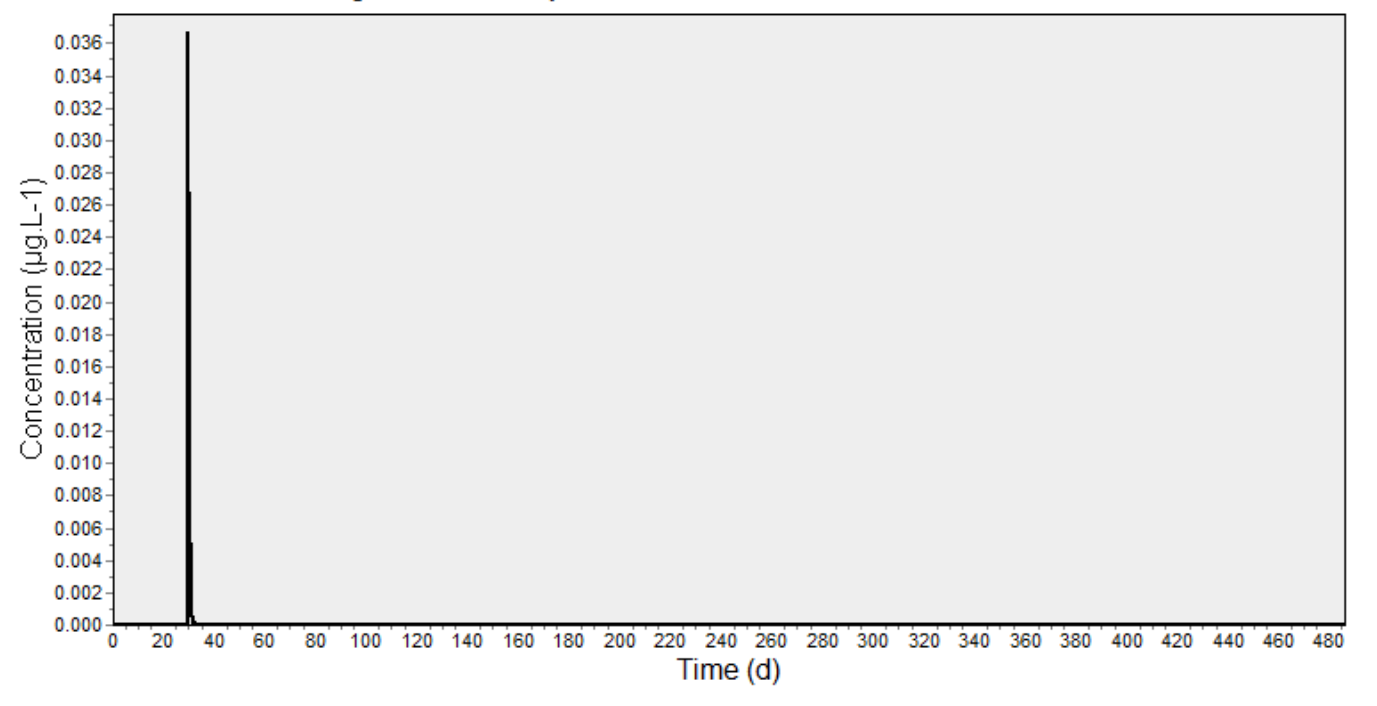




\section{Published documents in the Technical reports series of the Statutory Research Tasks Unit for Nature \& the Environment.}

WOt-technical reports are available from the secretary's office, T 0317 - 4854 71; E info.wnm@wur.nl Reports can also be downloaded from www.wur.nl/wotnatuurenmilieu.

113 Arets, E.J.M.M., J.W.H van der Kolk, G.M. Hengeveld, J.P. Lesschen, H. Kramer, P.J. Kuikman \& M.J. Schelhaas (2018). Greenhouse gas reporting for the LULUCF sector in the Netherlands. Methodological background, update 2018

114 Bos-Groenendijk, G.I. en C.A.M. van Swaay (2018). Standaard Data Formulieren Natura 2000-gebieden; Aanvullingen vanwege wijzigingen in Natura 2000 aanwijzingsbes/uiten

115 Vonk, J. , S.M. van der Sluis, A. Bannink, C. van Bruggen, C.M. Groenestein, J.F.M. Huijsmans, J.W.H. van der Kolk, L.A. Lagerwerf, H.H. Luesink, S.V. Oude Voshaar \& G.L. Velthof (2018.) Methodology for estimating emissions from agriculture in the Netherlands - update 2018. Calculations of $\mathrm{CH} 4, \mathrm{NH} 3, \mathrm{~N} 2 \mathrm{O}, \mathrm{NOx}, \mathrm{PM} 10, \mathrm{PM} 2.5$ and $\mathrm{CO} 2$ with the National Emission Model for Agriculture (NEMA)

116 IJsseldijk, L.L., M.J.L. Kik, \& A. Gröne (2018). Postmortaal onderzoek van bruinvissen (Phocoena phocoena) uit Nederlandse wateren, 2017. Biologische gegevens, gezondheidsstatus en doodsoorzaken.

117 Mattijssen, T.J.M. \& I.J. Terluin (2018). Ecologische citizen science; een weg naar grotere maatschappelijke betrokkenheid bij de natuur?

118 Aalbers, C.B.E.M., D. A. Kamphorst \& F. Langers (2018). Bedrijfs- en burgerinitiatieven in stedelijke natuur. Hun succesfactoren en knelpunten en hoe de lokale overheid ze kan helpen slagen.

119 Bruggen, C. van, A. Bannink, C.M. Groenestein, J.F.M Huijsmans, L.A. Lagerwerf, H.H. Luesink, S.M. van der Sluis, G.L. Velthof \& J. Vonk (2018). Emissies naar lucht uit de landbouw in 2016. Berekeningen met het model NEMA

120 Sanders, M.E., F. Langers, R.J.H.G. Henkens, J.L.M. Donders, R.I. van Dam, T.J.M. Mattijssen \& A.E. Buijs (2018). Maatschappelijke initiatieven voor natuur en biodiversiteit; Een schets van de reikwijdte en ecologische effecten en potenties van maatschappelijke initiatieven voor natuur in feiten en cijfers

121 Farjon, J.M.J., A.L. Gerritsen, J.L.M. Donders, F. Langers \& W. Nieuwenhuizen (2018). Condities voor natuurinclusief handelen. Analyse van vier praktijken van natuurinclusief ondernemen

122 Gerritsen, A.L., D.A. Kamphorst \& W. Nieuwenhuizen (2018). Instrumenten voor maatschappelijke betrokkenheid. Overzicht en analyse van vier cases

123 Vullings, L.A.E., A.E. Buijs, J.L.M. Donders, D.A. Kamphorst, H. Kramer \& S. de Vries (2018). Monitoring van groene burgerinitiatieven; Analyse van de resultaten van een pilot en nulmeting in vier gemeenten

124 Boonstra, F.G., Th.C.P. Melman, W. Nieuwenhuizen \& A. Gerritsen (2018). Aanpak evaluatie stelselvernieuwing agrarisch natuurbeheer; Uitgangspunten en opties voor een beleidsevaluatie

125 Vullings, L.A.E., A.E. Buijs, J.L.M. Donders \& D.A. Kamphorst (2018). Monitoring van groene burgerinitiatieven; Methodiek, indicatoren en ervaring met pilot en nulmeting.

126 Beltman, W.H.J., M.M.S. ter Horst, P.I. Adriaanse \& A. de Jong (2018). Manual for FOCUS_TOXSWA v5.5.3 and for expert use of TOXSWA kernel v3.3; User's Guide version 5

127 Van der Heide, C.M. \& M.M.M. Overbeek (2018). Natuurinclusief handelen en ondernemen. Scopingstudie 'Bedrijven, economie en natuur'

128 Langers, F. (2018). Recreatie in groenblauwe gebieden; Actualisatie van CLO-indicator 1258 (Bezoek aan groenblauwe gebieden) op basis van data van het Continu Vrijetijdsonderzoek uit 2015

129 Glorius, S.T., I.Y.M. Tulp, A. Meijboom, L.J. Bolle and C. Chen (2018). Developments in benthos and fish in gullies in an area closed for human use in the Wadden Sea; 2002-2016

130 Kamphorst, D.A \& T.J.M. Mattijssen (2018). Scopingstudie Vermaatschappelijking van natuur. Een overzicht van onderzoek bij Wageningen Universiteit \& Research voor het Planbureau voor de Leefomgeving en het ministerie van Landbouw, Natuur en Voedselkwaliteit

131 Breman, B.C., T.J.M. Mattijssen \& T.M. Stevens (2018). Natuur 2.0. Het natuurdebat op social media.

132 Vries, S. de \& W. Nieuwenhuizen (2018) HappyHier: hoe gelukkig is men waar?; Gegevensverzameling en bepaling van de invloed van het type grondgebruik, deel II

133 Kistenkas, F.H., W. Nieuwenhuizen, D.A. Kamphorst \& M.E.A. Broekmeyer (2018). Natuur- en landschap in de Omgevingswet.

134 Michels, R, V. Diogo, W.H.G.J. Hennen, L.F. Puister (2018). Instrumentarium Kosten Natuurbeleid 2018 - Status A; IKN versie 3.0

135 Sanders, M.E. (2018). Voortgang realisatie natuurnetwerk. Technische achtergronden bij de digitale Balans van de Leefomgeving 2018

136 Koffijberg K., J.S.M. Cremer, P. de Boer, J. Nienhuis, K. Oosterbeek \& J. Postma (2018). Broedsucces van kustbroedvogels in de Waddenzee in 2017 
137 Egmond, F.M. van, S. van der Veeke, M. Knotters, R.L. Koomans, D. Walvoort, J. Limburg (2018). Mapping soil texture with a gamma-ray spectrometer: comparison between UAV and proximal measurements and traditional sampling; Validation study

138 Glorius, S.T., A. Meijboom, J.T. Wal van der, J.S.M. Cremer (2018). Ontwikkeling van enkele droogvallende mosselbanken in de Nederlandse Waddenzee; situatie 2017.

139 Berg, F. van den, A. Tiktak, D.W.G. van Kraalingen, J.G. Groenwold \& J.J.T.I. Boesten (2018). User manual for GeoPEARL version 4.4.4.

140 Kuiters, A.T., G.A. de Groot, D.R. Lammertsma, H.A.H. Jansman \& J. Bovenschen (2018). Genetische monitoring van de Nederlandse otterpopulatie; Ontwikkeling van populatieomvang en genetische status 2017/2018

141 Müskens G.J.D.M., M.J.J. La Haye, R.J.M. van Kats \& A.T. Kuiters (2018). Ontwikkeling van de hamsterpopulatie in Limburg. Stand van zaken voorjaar 2018

142 Glorius, S.T. (2018). Ontwikkeling van de bodemdiergemeenschap in de geulen van referentiegebied Rottum; Tussenrapportage twaalf jaar na sluiting (najaar 2017).

143 Brouwer, F., F. de Vries en D.J.J. Walvoort (2018). Basisregistratie Ondergrond (BRO); Actualisatie bodemkaart: herkartering van de bodem in Flevoland

144 Knotters, M. en F.M. van Egmond (2018). Selectie van inwinningstechnieken voor bodemdata; Selecteren vanuit de (onderzoeks)vraag

145 Stuyt, L.C.P.M., M. Knotters, D.J.J. Walvoort, F. Brouwer \& H.T.L. Massop (2018). Basisregistratie Ondergrond - Gd-kartering Laag-Nederland 2018; Provincie Flevoland

146 Arets, E.J.M.M., J.W.H van der Kolk, G.M. Hengeveld, J.P. Lesschen, H. Kramer, P.J. Kuikman \& M.J. Schelhaas (2019). Greenhouse gas reporting of the LULUCF sector in the Netherlands. Methodological background, update 2019

147 Bruggen, C. van, A. Bannink, C.M. Groenestein, J.F.M. Huijsmans, L.A. Lagerwerf, H.H. Luesink, S.M. van der Sluis, G.L. Velthof \& J. Vonk (2019). Emissies naar lucht uit de landbouw in 2017. Berekeningen met het model NEMA.

148 Lagerwerf, L.A., A. Bannink, C. van Bruggen, C.M. Groenestein, J.F.M. Huijsmans, J.W.H. van der Kolk, H.H. Luesink, S.M. van der Sluis, G.L. Velthof \& J. Vonk (2019). Methodology for estimating emissions from agriculture in the Netherlands. Calculations of $\mathrm{CH} 4, \mathrm{NH} 3, \mathrm{N2O}, \mathrm{NOX}, \mathrm{NMVOC}$, PM10, PM2.5 and $\mathrm{CO} 2$ with the National Emission Model for Agriculture (NEMA) - update 2019.

149 Bakker, G., M. Heinen, H.P.A. Gooren, W.J.M. de Groot, F.B.T. Assinck \& E.W.J. Hummelink (2019). Hydrofysische gegevens van de bodem in de
Basisregistratie Ondergrond (BRO) en het Bodemkundig Informatie Systeem (BIS); Update 2018.

150 IJsseldijk, L.L., M.J.L. Kik, \& A. Gröne (2019). Postmortaal onderzoek van bruinvissen (Phocoena phocoena) uit Nederlandse wateren, 2018. Biologische gegevens, gezondheidsstatus en doodsoorzaken.

151 Daamen, W.P., A.P.P.M. Clerkx \& M.J. Schelhaas (2019). Veldinstructie Zevende Nederlandse Bosinventarisatie (2017-2021); Versie 2.0.

152 Bikker, P., L.B. Šebek, C. van Bruggen \& O. Oenema (2019). Stikstof- en fosfaatexcretie van gangbaar en biologisch gehouden landbouwhuisdieren. Herziening excretieforfaits Meststoffenwet 2019.

153 Berg, F. van den, H. Baveco \& E.L. Wipfler (2019). User manual for SAFE (Select Application date For Evaluation) to support the use of the GEM scenarios for cultivations in glasshouses; Version 1.1

154 Os, J. van, L.J.J. Jeurissen en H.H. Ellen (2019). Rekenregels pluimvee voor de Landbouwtelling; Verantwoording van het gebruik van het Identificatie- \& Registratiesysteem.

155 Brouwer, F. \& D.J.J. Walvoort (2019). Basisregistratie Ondergrond (BRO) - Actualisatie bodemkaart; Herkartering van de veengebieden in Eemland

156 Sanders, M.E., R.J.H.G. Henkens \& D.M.E. Slijkerman (2019). Convention on Biological Diversity; Sixth National Report of the Kingdom of the Netherlands.

157 Kuiters, A.T., G.A. de Groot, D.R. Lammertsma, H.A.H. Jansman, J. Bovenschen, M.C. Boerwinkel \& M. Laar (2019). Genetische monitoring van de Nederlandse otterpopulatie; Ontwikkeling van populatieomvang en genetische status 2018/2019.

158 Sanders, M.E. \& H.A.M. Meeuwsen (2019). Basisbestand Natuur en Landschap

159 Visser, T., H.A.M Meeuwsen \& Th.C.P. Melman (2019). MNP-(Model for Nature Policy) Agrarisch; Uitwerking voor scenario's uit de Natuurverkenning 2020.

160 Jong, A. de, A. Poot \& P.I. Adriaanse (2019). Impact analysis for the purpose of the introduction of DROPLET version 1.3.2. 



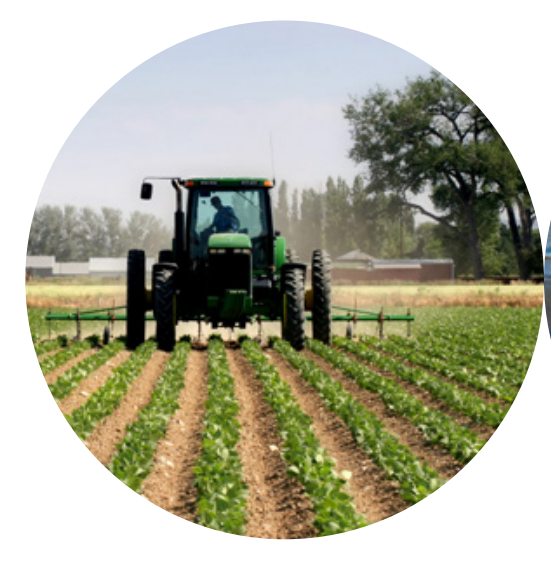

Theme agri-environment Wettelijke Onderzoekstaken Natuur \& Milieu

P.O. Box 47

6700 AA Wageningen

T (0317) 485471

E info.wnm@wur.nl

ISSN 2352-2739

www.wur.nl/wotnatuurenmilieu

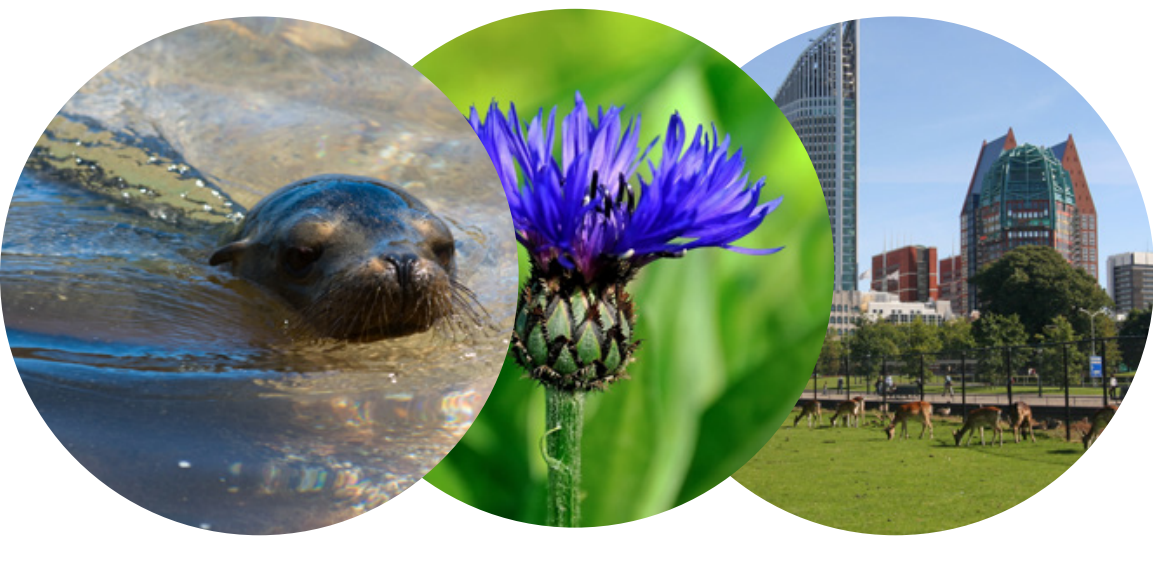

The mission of Wageningen University and Research is "To explore the potential of nature to improve the quality of life". Under the banner Wageningen University \& Research, Wageningen University and the specialised research institutes of the Wageningen Research Foundation have joined forces in contributing to finding solutions to important questions in the domain of healthy food and living environment. With its roughly 30 branches, 5,000 employees and 10,000 students, Wageningen University \& Research is one of the leading organisations in its domain. The unique Wageningen approach lies in its integrated approach to issues and the collaboration between different disciplines.

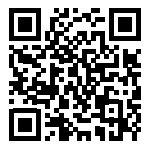

